\title{
Chronic obstructive pulmonary disease with mild airflow limitation: current knowledge and proposal for future research - a consensus document from six scientific societies
}

\author{
This article was published in the following Dove Press journal: \\ International Journal of COPD \\ 29 August 2017 \\ Number of times this article has been viewed
}

\begin{abstract}
Andrea Rossi,' Bojana ButoracPetanjek, ${ }^{2}$ Marco Chilosi, ${ }^{3}$ Borja G Cosío, ${ }^{4}$ Matjaz Flezar, ${ }^{5}$ Nikolaos Koulouris, ${ }^{6}$ José Marin, ${ }^{7}$ Neven Miculinic, ${ }^{2}$ Guido Polese, ${ }^{8}$ Miroslav Samaržija, ${ }^{9}$ Sabina Skrgat, ${ }^{5}$ Theodoros Vassilakopoulos, ${ }^{10}$ Andrea VukićDugac, ${ }^{9}$ Spyridon Zakynthinos, ${ }^{10}$ Marc Miravitlles"

'Pulmonary Unit, University of Verona, Verona, Italy; ${ }^{2}$ Respiratory Department, University Hospital Centre, Zagreb, Croatia; ${ }^{3}$ Pathology Unit, University of Verona, Verona, Italy; ${ }^{4}$ Department of Respiratory Medicine, Hospital Son Espases-IdISPa and CIBERES, Palma, Spain; ${ }^{5}$ University Clinic of Respiratory and Allergic Diseases, Golnik, Slovenia; ${ }^{6}$ First Department of Respiratory Medicine, Medical School of National and Kapodistrian University of Athens, Greece; ${ }^{7}$ Respiratory Medicine, Hospital Universitario Miguel Servet, CIBERES \& IISAragon, Zaragoza, Spain; ${ }^{8}$ Pulmonary Unit, ULSS 22 Bussolengo, Italy; 'Jordanovac Department for Respiratory Diseases, University of Zagreb School of Medicine, University Hospital Centre, Zagreb, Croatia; ${ }^{10}$ First Department of Critical Care and Pulmonary Services, Evangelismos Hospital, University of Athens, Greece; 'Pneumology Department, Hospital Universitary Vall d'Hebron, Barcelona, Spain
\end{abstract}

Abstract: Chronic obstructive pulmonary disease (COPD) is a leading cause of mortality and morbidity worldwide, with high and growing prevalence. Its underdiagnosis and hence undertreatment is a general feature across all countries. This is particularly true for the mild or early stages of the disease, when symptoms do not yet interfere with daily living activities and both patients and doctors are likely to underestimate the presence of the disease. A diagnosis of COPD requires spirometry in subjects with a history of exposure to known risk factors and symptoms. Postbronchodilator forced expiratory volume in 1 second $\left(\mathrm{FEV}_{1}\right)$ /forced vital capacity $<0.7$ or less than the lower limit of normal confirms the presence of airflow limitation, the severity of which can be measured by FEV $\%$ predicted: stage 1 defines COPD with mild airflow limitation, which means postbronchodilator $\mathrm{FEV}_{1} \geq 80 \%$ predicted. In recent years, an elegant series of studies has shown that "exclusive reliance on spirometry, in patients with mild airflow limitation, may result in underestimation of clinically important physiologic impairment". In fact, exercise tolerance, diffusing capacity, and gas exchange can be impaired in subjects at a mild stage of airflow limitation. Furthermore, growing evidence indicates that smokers without overt abnormal spirometry have respiratory symptoms and undergo therapy. This is an essential issue in COPD. In fact, on one hand, airflow limitation, even mild, can unduly limit the patient's physical activity, with deleterious consequences on quality of life and even survival; on the other hand, particularly in younger subjects, mild airflow limitation might coincide with the early stage of the disease. Therefore, we thought that it was worthwhile to analyze further and discuss this stage of "mild COPD". To this end, representatives of scientific societies from five European countries have met and developed this document to stimulate the attention of the scientific community on COPD with "mild" airflow limitation. The aim of this document is to highlight some key features of this important concept and help the practicing physician to understand better what is behind "mild" COPD. Future research should address two major issues: first, whether mild airflow limitation represents an early stage of COPD and what the mechanisms underlying the evolution to more severe stages of the disease are; and second, not far removed from the first, whether regular treatment should be considered for COPD patients with mild airflow limitation, either to prevent progression of the disease or to encourage and improve physical activity or both.

Keywords: chronic obstructive pulmonary disease, COPD, airflow limitation, COPD staging, GOLD document, COPD pathophysiology

\section{Background and aim}

Chronic obstructive pulmonary disease (COPD) is a leading cause of mortality and morbidity worldwide, ${ }^{1,2}$ with high and growing prevalence regionally and globally. ${ }^{3}$
Correspondence: Andrea Rossi UOC Pneumologia, Azienda OspedalieraUniversitaria Integrata, I Piazzale Stefani, Verona 37 I 26, Italy

Tel +39045812 2438

Email andrea.rossi@aiporicerche.it 
A recent review suggests that there is a trend of decreasing mortality for COPD in men, whereas it is increasing in women. ${ }^{4}$ Its underdiagnosis and hence undertreatment is a general feature across all countries. ${ }^{5}$ This is particularly true for the mild or early stages of the disease, when symptoms may not yet interfere with daily living activities, and both patients and doctors are likely to underestimate the presence of the disease.

A diagnosis of COPD requires spirometry in subjects with a history of exposure to known risk factors, cigarette smoking in particular, and such symptoms as dyspnea and/or chronic cough with sputum production. Postbronchodilator forced expiratory volume in 1 second $\left(\mathrm{FEV}_{1}\right) /$ forced vital capacity (FVC) $<0.7$ or below the lower limit of normal (LLN) confirms the presence of persistent airflow limitation, the severity of which can be assessed by means of the value of $\mathrm{FEV}_{1} \%$ predicted: the stage/grade 1 defines COPD with mild airflow limitation, which means postbronchodilator $\mathrm{FEV}_{1} \geq 80 \%$ predicted. $^{1}$

The recent GOLD (Global Initiative for Chronic Obstructive Lung Disease) document, though recognizing some "imperfection" of that choice, confirms the postbronchodilator $\mathrm{FEV}_{1}$ :FVC $<0.7$ criterion for the diagnosis of persistent airflow limitation for its diagnostic simplicity and consistency. Adoption of the LLN values, as recommended by the European Respiratory Society-American Thoracic Society task force on lung-function tests, ${ }^{6}$ would be even more "imperfect", according to the GOLD document, due to biases caused by age, height, and sex differences. ${ }^{1}$ However, a prospective comparison between both spirometric criteria and an expert-based diagnosis of COPD concluded that the fixed ratio and the LLN overestimated and underestimated, respectively, the presence of COPD in elderly subjects, ${ }^{7}$ the authors recommended incorporation of $\mathrm{FEV}_{1}$ and residual volume (RV)/total lung capacity (TLC) in the COPD definition. ${ }^{7}$ A new approach to normal spirometry was provided by the Global Lung Initiative (GLI), a European Respiratory Society task force, which made available a spirometric prediction equation for the age-group 3-95 years applicable to different ethnic groups (Caucasian, AfricanAmerican, Asian). ${ }^{8} Z$-scores were calculated for spirometric variables and compared to fixed-ratio data, suggesting that the $\mathrm{FEV}_{1}: \mathrm{FVC}<0.7$ ratio would misclassify individuals, with GLI-defined normal spirometry, as having respiratory impairment. ${ }^{9,10}$ Quanjer et al recommend the use of the GLI equations ${ }^{8}$ coupled with standardization in testing methodology ${ }^{11}$ for interpretation of spirometry free of major sources of bias. ${ }^{12}$
Although other factors, such as symptoms, exacerbations, complications, and comorbidities, are considered in classification of the overall severity of the disease, ${ }^{1}$ spirometry remains a cornerstone, at least for the initial evaluation. Probably most patients with mild airflow limitation fit the A category of new GOLD staging, but in more infrequent cases patients with mild COPD may be classified in any of the new GOLD categories, A-D. ${ }^{1}$

In recent years, an elegant series of studies showed that "exclusive reliance on spirometry, in COPD patients with mild airflow limitation, may result in underestimation of clinically important physiologic impairment". ${ }^{13}$ This is an essential issue in COPD. In fact, on one hand, airflow limitation, even mild, can unduly limit the patient's physical activity; ${ }^{14,15}$ on the other hand, particularly in younger subjects, mild airflow limitation might coincide with the early stage of the disease. ${ }^{16,17}$ In this connection, it is worthy of note that the mean age of COPD patients does not differ very much among stages, from mild to severe and very severe, in large trials ${ }^{18}$ or observational ${ }^{19,20}$ and physiologic studies. ${ }^{21,22}$ This suggests that in some subjects, mild airflow limitation might be the only physiologic phenotype of the disease, while in others it could represent the first stage toward a progressive deterioration in lung function. Therefore, we thought it worthwhile to analyze further and discuss this stage of "mild COPD". ${ }^{23}$

To this end, representatives of scientific societies from five European countries have met and developed this document to stimulate the attention of the scientific community on COPD with "mild" airflow limitation. The aim of this document is to highlight some key features of this important concept and help the practicing physician to understand better what is behind "mild" COPD.

It has been known for many years that smokers, with relatively preserved $\mathrm{FEV}_{1}$ and conventional spirometry within normal limits, may have extensive small-airway impairment, eg, hypersecretion and inflammation, ${ }^{24-26}$ with physiologic abnormalities, which can be measured by means of adequate physiologic tests and are not detectable in otherwise healthy nonsmokers. ${ }^{14,27-30}$ Pathologic abnormalities in the periphery of the lungs not yet detectable with spirometry may explain the growing prevalence of symptomatic smokers, even requiring pharmacologic treatment, with spirometry still within the normal limits. ${ }^{31,32}$ A simplified view of the natural history of COPD might assume that small-airway disease in smokers can progress to mild airflow limitation, which deteriorates to moderate and severe lung-function impairment and eventually respiratory failure. Unfortunately, this 
attractive hypothesis has not yet received sufficient experimental support from longitudinal surveys.

In 1977, Fletcher and Peto showed that there is a group of susceptible smokers with an enhanced decline in lung function with age. ${ }^{33}$ Despite well-known methodological limitations, ${ }^{34}$ this seminal study has constituted the reference model for our understanding of the natural history of COPD for the past 40 years. Recent research, however, has shown that it does not reflect reality accurately. ${ }^{35}$ On one hand, accelerated loss of lung function is not present in $40 \%$ of patients diagnosed and treated for COPD; ${ }^{36}$ on the other, a number of potential factors, such as the effect of lung development during childhood and adolescence, ${ }^{37,38}$ the role of bronchial hyperresponsiveness, and/or the role of infection, among others, can influence the risk of developing the disease or its progression with time from early stages. ${ }^{39}$

In this context, it is important to reiterate that "mild disease" is not necessarily synonymous with "early disease". ${ }^{16}$ The latter refers to an initial time point during the course of the disease. Young age is a natural surrogate of early disease; by contrast, the former refers to the severity of the disease, which may be independent of age, eg, a 75-year-old patient with mild airflow limitation.

Little is known about the early stages of COPD, ${ }^{16,17,39}$ because most patients are either not diagnosed or diagnosed at the age of 60/70 years, when they have already developed moderate-severe disease. Population studies, such as the European Community Respiratory Health Survey (ECRHS) ${ }^{40}$ and the EPISCAN in Spain, ${ }^{41}$ estimated a prevalence of COPD in the age-group $40-49$ years of $3.6 \%$ and $3.8 \%$ ( $4.4 \%$ in men and $3.2 \%$ in women), respectively. Furthermore, in both studies, the diagnosis of COPD was associated with poorer quality of life and greater use of health resources. Clearly, the presence of mild airflow limitation at the age of 50 years or less has greater clinical relevance than at the age of 70 years.

The clinical/biological determinants of progression from early COPD are unclear. Some studies indicate that the majority of patients in GOLD grade 1 (recognizing that this may not necessarily mean early COPD, but mild airflow limitation) do not develop clinically significant COPD, even if the person continues smoking. ${ }^{42}$ Other studies report that lung-function decline is faster in the mild-moderate stages of the disease, ${ }^{43,44}$ mainly among symptomatic patients, ${ }^{45}$ and in patients who have recurrent lower respiratory tract infections and continue to smoke. ${ }^{46}$ Furthermore, it has been demonstrated that exacerbations accelerate the loss of lung function more in patients with mild than with severe COPD. ${ }^{47}$
Also of interest is the association of COPD grade 1 with other diseases. It has been reported that patients in GOLD grade 1 (mild airflow limitation, but not necessarily early disease) have a threefold risk to develop depression ${ }^{48}$ or increased risk of lung cancer ${ }^{49}$ than healthy controls.

Biomarkers of disease activity/progression in early COPD are unknown. Recently, $\mathrm{CC} 16,{ }^{50} \mathrm{SPD},{ }^{51}$ and a battery of six markers of persistent systemic inflammation ${ }^{52}$ have been proposed as biomarkers of disease progression. However, none of them has been studied in COPD patients with mild airflow limitation, and other potential markers of progression, such as changes in the microbiome or genetic factors, have not been explored. Since several pathogenic processes could be active in the same individual, these processes can be present at different times in the individual patient. ${ }^{16}$

\section{Epidemiology}

Many epidemiological surveys have documented the high prevalence of COPD in the general adult population, in both men and women. In fact, the prevalence is consistently higher in men, and rises with age. Clearly, COPD is much more frequent in smokers and ex-smokers, but with a contribution also from never-smokers. Most publications report the data organized by age-groups and smoking habits, not by stages of severity. However, few studies have provided the classification of the COPD population according to the GOLD 2007 stages of airflow limitation. ${ }^{53}$

The BOLD epidemiological research reports data on 9,425 men and women from 12 countries worldwide. The diagnosis of COPD was based on postbronchodilator $\mathrm{FEV}_{1}: \mathrm{FVC}<0.7 .{ }^{54}$ Overall, the prevalence of airflow limitation in the different countries ranged from $11.3 \%$ to $26 \%$, increasing consistently through age-groups from 40 to $>70$ years. Grade 2 or more averaged $11.8 \%$ and $8.5 \%$ in men and women, respectively. The prevalence of grade 1 ranged from $1.4 \%$ to $15.5 \%$, with an average of $8.1 \%$, being $6.7 \%$ and $9.6 \%$ in women and men, respectively. A subsequent analysis focused on the difference between eversmokers $(5,709)$ and never-smokers $(4,291)$. Overall, $12.2 \%$ never-smokers fulfilled the criteria for GOLD COPD, 6.6\% being classified as GOLD 1. Furthermore, never-smokers made up $27.7 \%$ of all COPD cases and 33\% of GOLD 1. GOLD 1 amounted to $8.3 \%$ of cases in men and $5.7 \%$ in women. These data show that COPD with mild airflow limitation is a real issue in the COPD population, and in particular among never-smokers. ${ }^{55}$

In the Spanish investigation on 4,274 adults aged 40-80 years, 3,802 subjects underwent good-quality 
postbronchodilator spirometry. ${ }^{41}$ The overall prevalence of airflow limitation was $10.2 \%, 15.1 \%$ in men, and $5.6 \%$ in women, and $7.1 \%$ and $2 \%$ in GOLD 2-4 respectively, increasing with age and smoking habits. COPD prevalence by GOLD classification of severity gave the following results: mild $56.4 \%$, moderate $38.3 \%$, severe $4.6 \%$, and very severe $0.5 \%$. The ECRHS study on more than 18,000 young adults (20-44 years) from 35 sites in 16 "high-income" countries showed stage 1 and stage 2-4 prevalence of $2.5 \%$ and $1.1 \%$, respectively, ${ }^{40}$ with an overall prevalence of COPD amounting to $3.6 \%$. The diagnosis of airflow limitation was obtained with spirometric measurement of prebronchodilator $\mathrm{FEV}_{1}: \mathrm{FVC}<0.7$. Both the BOLD and the ECRHS surveys showed a remarkable difference in prevalence among countries. In the COPDGene cross-sectional observational study on 9,000 subjects, 9\% were classified as GOLD 1, with a mean age of 61 years, slightly lower and higher than GOLD 2-4 and GOLD 0, with average mean ages of 63 and 56 years, respectively. ${ }^{32}$

A crucial issue is whether COPD patients with mild airflow limitation sought contact with doctors. The Italian survey on COPD showed that $18.2 \%$ of the about 4,000 COPD patients referred to pulmonary clinics in Italy had mild airflow limitation and that $86 \%$ received some pharmacologic treatment (long-acting bronchodilators and/or inhaled corticosteroids). ${ }^{19}$ However, the prevalence of reported exacerbations and comorbidities was $44.5 \%$ and $64 \%$, respectively, the latter not far from the $81 \%$ of patients with very severe airflow limitation. This study suggests that COPD patients with mild airflow limitation are likely to seek doctors and even pulmonologists more for exacerbations and/or comorbidities, rather than common respiratory symptoms, such as dyspnea or cough. However, the ECLIPSE study ${ }^{18}$ reported that the majority of COPD patients with moderate-severe airflow limitation were not frequent exacerbators. In fact, the 2-year follow-up data from the DACCORD study ${ }^{20}$ showed that in a population of COPD patients with a low rate of exacerbation $(<0.4$ exacerbations/year), respiratory symptoms were a common cause for seeking medical help and should not be underestimated, as a significant improvement can be obtained with pharmacologic treatment. In the DACCORD population, almost $20 \%$ had mild airflow limitation..$^{20}$ In the longitudinal results from the COPDGene study ${ }^{47} 48$ of 185 COPD patients classified as GOLD 1 were receiving pharmacologic treatment with long-acting bronchodilators and/or inhaled corticosteroids at the 5-year visit.

Lange et al ${ }^{56}$ compared the mortality rate between the old $(2007)^{53}$ and the new (2011) ${ }^{1,57}$ GOLD classifications on 6,628 individuals with COPD in the Copenhagen study. Among the 3,306 (50\% of the total) patients with GOLD 1 airflow limitation, $90 \%$ were classified as $\mathrm{A}$, whereas $10 \%$ were classified as B, C, and D, ie, patients with symptoms and exacerbation risk. In that study, women were $54 \%$, and never-smokers $26 \%$ in GOLD stage 1 . Mortality averaged $0.7 \%$ and $4 \%$ after 1 and 3 years, respectively, compared to $2.2 \%$ and $25.8 \%$ in GOLD 2007 stage IV patients.

In Slovenia, the National Institute of Public Health (NIJZ) is a state institution that reports prevalence of diseases on national level. In the Supplementary material, data from 2008 are presented for a small region of northern Slovenia (with high prevalence of smoking, above the average Slovenian level). The striking finding is the high prevalence of smoking in younger adults, which is increasing mostly in young women. Overall prevalence of COPD in that region is 5.7\%, and in smokers $16.6 \%$.

\section{Pathology}

There is consensus on the notion that in COPD, inflammation in the small airways is related to cigarette smoking. However, the hypothesis of a central role of small-airway inflammation in the pathogenesis of COPD has been challenged by many recent studies. The role of premature lung aging has been proposed by many authors as central in the pathogenesis of COPD, ${ }^{58-60}$ where the critical balance between senescence and antisenescence factors is disrupted toward senescence in COPD lungs. ${ }^{61-66}$ Telomere attrition is anticipated in COPD lungs, and this view is further supported by the occurrence of relevant comorbidities, such as weight loss, osteoporosis, cardiovascular diseases, and depression, all conditions where premature senescence and telomere-length abnormalities have been documented ${ }^{65}$ Experimental studies have demonstrated that telomere length is a susceptibility factor in emphysema. ${ }^{66-68}$

The parenchymal remodeling and progressive dilation of alveolar spaces that is observed in emphysema is likely related to decreased and/or deregulated production of extracellularmatrix proteins, with eventual impaired capability to sustain connective and epithelial tissue repair. Several studies have evidenced connective tissue insufficiency leading to progressive decrease of matrix-protein production. ${ }^{66}$ Premature stem-cell exhaustion can represent the best candidate for this putative pathogenic mechanism. Senescence-related markers in COPD are mainly demonstrable in mesenchymal cells (fibroblasts and endothelial cells), ${ }^{68}$ and a large variety of abnormalities have been described affecting pulmonary mesenchymal precursors, fibroblasts, and endothelial cells in 
both human and experimental COPD. ${ }^{69-73}$ Notch and Wnt are signaling pathways involved in the correct differentiation of mesenchymal precursors. ${ }^{74-77}$ Insufficient local immunoregulation might explain the autoimmune-like chronic inflammation and damage of small airways in COPD. ${ }^{61,78}$

\section{Pathophysiology}

Knowledge of the pathophysiology of COPD with mild airflow limitation is essential to understand the changes taking place in the lungs before the development of more severe spirometric abnormality, ie, GOLD $\geq 2 .,{ }^{1,53,57}$ We can distinguish three levels: level 1 , in which the biologic and physiologic abnormalities in the small airways of smokers coexist with spirometric values within normal limits; ${ }^{14}$ level 2, COPD with mild airflow limitation (GOLD 2007 stage 1$) ;{ }^{.53}$ and level 3, COPD with moderate-severe and very severe airflow limitation (GOLD 2007 stage 2-4). 53,79

In level 1 (small-airway disease), pathobiological changes in the lungs can be detected by means of tests of small-airway function, which disclose abnormalities not present in healthy nonsmokers. ${ }^{80}$ The single-breath nitrogen-washout test exhibits a high nitrogen slope of the alveolar plateau $\left(\mathrm{N}_{2}\right.$ slope, phase III), closing volume, and closing capacity. ${ }^{29,81,82}$ Among the tests that detect small-airway disease, ${ }^{83-86}$ one of the most sensitive (yet not in widespread use) appears to be low-density spirometry, ${ }^{86}$ ie, assessing spirometric maximal expiratory flow volume before and after inhalation of heliox. The aforementioned tests are sufficiently sensitive indicators to allow detection of small-airway obstruction in smokers at a stage when the maximal expiratory flow-volume curve (while breathing air) is within normal limits. ${ }^{82}$ The majority of smokers (87\%) who developed abnormal $\mathrm{FEV}_{1}$ during a 9- to-11-year follow-up had an abnormal single-breath $\mathrm{N}_{2}$ test at some time prior to their $\mathrm{FEV}_{1}$ becoming abnormal. ${ }^{84}$ However, the positive predictive value of an abnormal single-breath $\mathrm{N}_{2}$ test is quite low, in that a large proportion of smokers with an abnormal single-breath $\mathrm{N}_{2}$ test do not progress to abnormal $\mathrm{FEV}_{1} \cdot{ }^{29,84}$ Recently, Elbehairy et al demonstrated that current symptomatic smokers who did not meet the spirometric criteria for an overt diagnosis of COPD had lower exercise tolerance, higher neuromuscular drive, and greater diaphragmatic effort than comparable healthy controls. ${ }^{14}$

It has been shown that pathologic abnormalities in the small airways were found in COPD patients with mild airflow limitation. ${ }^{25,60}$ Smokers with mean $\mathrm{FEV}_{1}: \mathrm{FVC}$ of $0.717 \pm 0.038$ but with small-airway disease detected by single-breath $\mathrm{N}_{2}$-washout test have reduced $\mathrm{FEV}_{1}$, and thus may be more susceptible to long-term smoking than smokers without small-airway disease to develop overt COPD ${ }^{87}$ In smok-

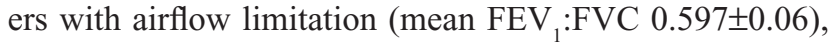
an abnormal single-breath $\mathrm{N}_{2}$-washout test predicted the development of low FEV 13 years later. ${ }^{29}$ Patients with mild COPD may exhibit resting lung hyperinflation with increases in functional residual capacity (FRC; 119\%-121\% predicted) and RV (129\%-135\% predicted) ${ }^{88,89}$ Mid-volume expiratory-flow rates are also reduced (forced expiratory flow $25 \%-75 \%$ and $50 \%){ }^{88,89}$ Measurement of respiratory resistance and impedance with the oscillatory technique also has the potential to assess mild COPD. Frantz et $\mathrm{al}^{90}$ showed that pulmonary resistance measured by means of the impulse-oscillation system can be abnormal earlier than conventional spirometry.

The majority of COPD patients with mild airflow limitation have a reduction in lung-diffusing capacity for carbon monoxide $\left(\mathrm{DL}_{\mathrm{CO}}\right),{ }^{91,92}$ though this reduction does not unanimously reach below $80 \%$ predicted. ${ }^{22,82,88,89}$ This reduction in diffusing capacity is a feature of both mild disease and early (and thus mild) disease. ${ }^{80}$ In fact, Harvey et al followed a cohort of smokers with normal spirometry for up to 13 years, and found that among those with low $\mathrm{DL}_{\mathrm{CO}}(<80 \%$ predicted $)$, ten $(22 \%)$ of 46 developed spirometric obstruction $\left(\mathrm{FEV}_{1}: \mathrm{FVC}<0.7\right)$, whereas among those with normal $\mathrm{DL}_{\mathrm{CO}}(\sim 80 \%)$, only two (3\%) of 59 developed spirometric obstruction. ${ }^{93}$ The result remained the same when either a fixed $\mathrm{FEV}_{1}: \mathrm{FVC}$ ratio $(<0.7)$ or the LLN (of $\mathrm{FEV}_{1}: \mathrm{FVC}<\mathrm{LLN}$ ) was used. ${ }^{94}$ Therefore, it stands to reason that diffusion impairment may occur before spirometric obstruction becomes manifest in the natural history of the disease.

On average, arterial blood gases are within the normal range in COPD patients with mild airflow limitation. ${ }^{22,91}$ However, the alveolar-arterial $\mathrm{O}_{2}$-tension gradient $\left(\mathrm{D}_{\mathrm{A}-\mathrm{a}} \mathrm{O}_{2}\right)$ is elevated $(>15 \mathrm{mmHg})$ at rest and during exercise. ${ }^{22,91,95,96}$ Ventilation-perfusion $\left(\dot{\mathrm{V}}_{\mathrm{a}}: \dot{\mathrm{Q}}\right)$ distribution, measured by means of the multiple inert-gas-elimination technique in patients with mild airflow limitation, unravels $\dot{\mathrm{V}}_{\mathrm{a}}: \dot{\mathrm{Q}}$ mismatching, predominantly perfusion dispersion, ${ }^{22,95}$ which is greater than predictable from the degree of airflow limitation, thus suggesting that COPD initially involves the periphery of the lungs, ie, small airways, parenchyma, and pulmonary vessels, with minimal or even negligible spirometric abnormalities. Recent data from the MESA study ${ }^{97}$ showed that pulmonary vascular blood flow was reduced in COPD patients with mild airflow limitation, and also in lung regions without obvious emphysema. 
In COPD patients with mild airflow limitation during exercise, minute ventilation is higher than in healthy control subjects at any given workload (in watts). Dyspnea, measured by means of the Borg scale, is greater at any level of minute ventilation, such that dyspnea is significantly greater at any given workload, and it is associated with a progressive decrease in inspiratory capacity, ie, dynamic hyperinflation, which does not occur in controls. ${ }^{89}$ Furthermore, minute ventilation $/ \mathrm{CO}_{2}$ production, dead space to tidal volume ratio $\left(\mathrm{V}_{\mathrm{D}}: \mathrm{V}_{\mathrm{T}}\right)$, and arterial to end-tidal $\mathrm{CO}_{2}$ difference are all higher than in healthy controls. ${ }^{91}$ Dynamic hyperinflation and tidal volume constraints result in a breathing pattern that becomes rapid and shallow. ${ }^{89,91}$ In those patients, the high $\mathrm{V}_{\mathrm{D}}: \mathrm{V}_{\mathrm{T}}$ leads to a compensatory rise in minute ventilation during exercise, thus maintaining effective alveolar ventilation and normal arterial blood gases, but at the expense of earlier dynamic mechanical abnormalities, greater dyspnea, and poor exercise tolerance.

Compared to healthy controls, subjects with mild airflow limitation at the highest equivalent work rate $(60 \mathrm{~W})$ have significantly higher total work of breathing, electromyographic activity of the diaphragm $\left(\mathrm{EMG}_{\mathrm{di}}\right)$ and $\mathrm{EMG}_{\mathrm{di}}$ to transdiaphragmatic pressure $\left(\mathrm{P}_{\mathrm{di}}\right)$ ratio. ${ }^{92}$ These findings indicate that greater neuromuscular drive $\left(\mathrm{EMG}_{\mathrm{di}}\right)$ is needed at any given level of diaphragmatic effort $\left(\mathrm{P}_{\mathrm{di}}\right)$. Furthermore, dyspnea-ventilation slopes are significantly higher in mild COPD than controls. Therefore, increased inspiratory effort and work in breathing and wider dissociation between diaphragmatic activation and pressure-generating capacity are observed at fixed work rates in subjects with mild COPD than in control subjects. In line with these mechanical and neuromuscular abnormalities, dyspnea is greater than in controls. Although significant dyspnea is experienced only at higher exercise work rates, overall exercise tolerance is reduced in COPD patients with mild airflow limitation compared to healthy controls.

Traditionally, the impairment of cardiac function is regarded as a late complication of severe COPD, affecting the right sections of the heart, a clinical picture known as cor pulmonale. However, in a cardiovascular disease-free study population, Barr et a ${ }^{98}$ showed that subclinical hemodynamic changes involving the left ventricle occur with mild emphysema and airflow limitation.

In summary, "mild" spirometric abnormality, or even normal spirometry in smokers, ${ }^{14}$ is associated with important physiologic disturbances that may not manifest at rest and generate symptoms, ie, dyspnea, only during moderate-high levels of exercise. This may explain why this stage of COPD does not attract the attention of either the patient or the doctor until exercise intolerance reaches a level that interferes with daily life activities. ${ }^{30}$

\section{Imaging}

Chest X-ray is a standard part of the clinical evaluation of subjects with COPD, but it lacks sensitivity in detecting both airway disease and mild emphysema. The utility of chest X-ray is limited to exclude other conditions that may imitate COPD or complications, such as pneumonia. By contrast, techniques in chest imaging and quantitative image analysis have advanced to the point where they can provide novel in vivo insight into disease and potentially examine divergent responses to therapy. Computed tomography (CT) of the chest has become the standard method used for objective visualization of the lungs in COPD. It can provide useful measures of emphysema, airway-wall thickening, and air trapping associated with the disease. ${ }^{32,99-101}$ Previous studies have shown that emphysema and airway-wall thickening on CT relate poorly to pulmonary function. The sensitivity of high-resolution CT in detecting early emphysema can be low, but its accuracy is greater than pulmonary function tests. ${ }^{100,101}$ The population-based study of Barr et al showed that significant emphysema can be detected by means of the thoracic CT scan in subjects with preserved spirometric values. ${ }^{98}$ The COPDGene study showed that $81 \%$ of GOLD 1 and $42 \%$ of GOLD 0 patients had evidence of emphysema or airway disease by means of quantitative CT-scan analysis. ${ }^{32}$ In GOLD 1 patients, 67\% showed airway thickening and $68 \%$ predominant emphysema. In GOLD 2-4 patients, $100 \%$ had quantitative CT-scan abnormalities. Quantitative $\mathrm{CT}$ evidence of hyperinflation of the lungs predicts a rapid annual decline in $\mathrm{FEV}_{1}$ in smokers with normal $\mathrm{FEV}_{1}{ }^{102}$ The ECLIPSE study showed that the prevalence of all patterns of emphysema clearly increased across the GOLD grades, and emphysema was almost universally found in GOLD 4 patients. ${ }^{103}$ Bronchial wall thickening also increased in prevalence with GOLD grade, while centrilobular nodularity decreased in prevalence. CT lung-density measurements are used for the evaluation of the degree and the distribution of emphysema and air-wall dimensions. An elegant study from Jones et al ${ }^{104}$ found a significant correlation between the ventilatory response to exercise $\left(\dot{\mathrm{V}}_{\mathrm{E}} / \dot{\mathrm{V}}_{\mathrm{CO}_{2}}\right)$ and emphysema severity. This in turn was related to reduced diffusing capacity, but not to airway-wall thickness, both assessed by means of CT.

Identification of the clinical, imaging, and genetic characteristics of GOLD 1 subjects with progressive disease could 
provide opportunities for early treatment interventions. ${ }^{105}$ The COPDGene study has reported epidemiological and radiological characteristics (quantitative CT lung-density measurements) of GOLD 1 subjects. Clustering of GOLD 1 subjects identified "near-normal", "airway-predominant", "emphysema-predominant", and "lowest $\mathrm{FEV}_{1} \%$ predicted" subtypes. This study demonstrated substantial clinical heterogeneity of COPD patients with mild airflow limitation. ${ }^{105}$ The COPDGene study included 10\% of GOLD 1 patients, who had clear abnormality of emphysema and/or small-airway disease at CT scan. Interestingly enough, these patients exhibited an $\mathrm{FEV}_{1}$ decline over 5 years of observation, which was significantly greater than in GOLD $2+$ patients. ${ }^{99}$ Furthermore, GOLD 1 subjects with positive anamnesis of exacerbations exhibited thicker airway walls and greater prevalence of chronic bronchitis than patients without exacerbation in the previous year. ${ }^{105}$ Although thoracic CT is a very powerful tool for investigating the periphery of the lungs and has generated many expectations for a new subclassification of COPD, it has not yet achieved success comparable with that obtained by high-resolution CT for interstitial lung diseases. ${ }^{106}$ Other imaging modalities are interesting tools for ascertaining the mild stages of COPD, but are far from influencing clinical practice. ${ }^{16}$

\section{Clinical}

Dyspnea is the most common symptom for which COPD patients seek medical advice. However, in patients with mild airflow limitation, dyspnea is perceived mainly with moderate-high levels of exercise, rather than at rest. ${ }^{13,89}$ Most COPD patients are smokers or aged ex-smokers, and hence they accept symptoms as direct consequences of both smoking and aging. Most often, patients choose to limit their physical activities to avoid the gradually emerging dyspnea on exertion. They often do not ask for medical care until the symptoms interfere with their daily life activity, which typically occurs in more severe disease. However, there is also a group of patients with slightly abnormal spirometry who are otherwise asymptomatic. Exerciseinduced shortness of breath is one of the earliest COPD symptoms, progressing over the course of the disease and often determining a significant reduction in activity levels, which in turn may cause deconditioning, skeletal muscle dysfunction, and further functional limitations. ${ }^{107}$ Recent studies have demonstrated muscle weakness of arms and legs in GOLD 1 patients, documenting that physical deconditioning is present in COPD patients with mild airflow limitation. ${ }^{107,108}$
Chronic bronchitis, ie, cough and sputum on most days for 3 consecutive months in 2 consecutive years, is frequent in smokers, and can be present with mild airflow limitation and even without airflow limitation, but it is associated with poorer health status and worse prognosis. ${ }^{109,110}$ The traditional physical examination is often negative in most COPD patients with mild airflow limitation.

Patients with mild airflow limitation are not a homogeneous group. Symptomatic patients have a faster rate of decline of lung function, lower health-related quality of life, and increased health utilization compared with asymptomatic individuals. ${ }^{107}$ Recent research has indicated that health care utilization and health-related quality of life are similar in asymptomatic patients with mild airflow limitation and in those with normal lung function. ${ }^{111}$ On the other hand, some patients have significant symptoms with near-normal lung function..$^{14}$ This could be attributed to excessive ventilatory demand with decreased inspiratory muscle pressuregenerating capacity due to dynamic hyperinflation, and ventilation-perfusion mismatching during exercise. ${ }^{107}$

Although COPD exacerbations are usually associated with more severe disease, they can occur in patients with GOLD 1 stage. In a 1 -year prospective study, $70 \%$ of patients with mild and moderate airflow limitation $\left(\mathrm{FEV}_{1} \geq 50 \%\right.$ predicted) reported at least one exacerbation. ${ }^{111}$ In the COPDGene study, ${ }^{47} 27.4 \%$ of GOLD 1 patients experienced one or more exacerbations during the 5 years of observations with a mean rate/year of 0.18 compared to 0.13 of GOLD 0 and 0.89 of GOLD 4 patients, respectively. In an Italian observational study on about 4,000 COPD patients, 745 were classified as GOLD 1; only 55\% reported being exacerbation-free, and $20 \%$ reported two or more exacerbations in the previous year, with $9.6 \%$ reporting one or more hospitalizations. ${ }^{19}$ A survey of 3,306 COPD patients classified as GOLD 1 showed that about 10\% were in categories B, $\mathrm{C}$, and D of the 2011 GOLD classification, suggesting that they had symptoms. About $1 \%$ were classified as $\mathrm{C}$ and $\mathrm{D}$, also indicating a high risk of exacerbation. ${ }^{54}$ In the GOLD 1 group, $2.5 \%$ of the mild group had exacerbations in the previous year. In the 3 years of observation, the average number of exacerbations per year was 0.1 , with 27 hospital admissions due to COPD and two respiratory deaths, while deaths from any causes increased from $4 \%$ to $5.9 \%, 14.3 \%$, and $25.8 \%$ from stage 1 to 4 .

In fact, the actual incidence of exacerbations in COPD with mild airflow limitation may be higher than expected, since many are likely to be unreported. ${ }^{107}$ In a study of patients with GOLD 1, the incidence of acute events was 
higher (1.8 episodes per year) than in controls (1.4 episodes per year). ${ }^{112}$ It has been documented that the occurrence of exacerbations is associated with faster loss of lung function in GOLD 1 and $2 .^{33}$

The overall burden of COPD is aggravated by comorbidities, which are often observed early in the disease progression. These include diabetes, cardiovascular disease, osteoporosis, gastroesophageal reflux, and depression. In the Italian survey, the presence of at least one comorbidity was reported by $64 \%$ of GOLD 1 patients compared to $81 \%$ of patients classified as GOLD 4. ${ }^{19}$ Patients with COPD are at greater risk of developing depression than demographically matched healthy controls, even at the mild stages of the disease. The ECLIPSE study reported that comorbidities were independent of severity of airflow limitation. ${ }^{113}$ However, in the German observational study, including almost $70 \%$ grades 1 and 2 COPD, the exacerbation rate was low, and such symptoms as dyspnea had a major impact on patients' lives. ${ }^{20}$

In conclusion, COPD patients with mild airflow limitation are likely to seek medical help more for different reasons, such as exacerbations, dyspnea, and comorbidities. In particular, however, episodes of mild exacerbation should draw the attention of the attending physician to a more complete evaluation of the patient's condition and to plan a follow-up program.

\section{Physical activity}

Particular attention should be devoted to the issue of physical activity in COPD patients with mild airflow limitation. Although specific studies on this subgroup of patients are lacking, several lines of evidence have shown that physical activity is consistently low in COPD patients at any stage, ${ }^{114}$ with deleterious consequences on decline in lung function, ${ }^{115}$ extrapulmonary effects, ${ }^{116}$ quality of life, and even survival. ${ }^{117,118}$ The mechanisms of interaction between physical (in)activity and the pathophysiology of chronic disorders is poorly understood, and certainly deserves future research. ${ }^{15}$ Rehabilitation programs give inconsistent results on physical activity, although sometimes the effect of rehabilitation is statistically significant. ${ }^{119}$ However, due to the beneficial effects, including the increased survival ${ }^{120}$, of physical activity in human beings, behavioral changes to a more active life, in addition to smoking-cessation programs, should be encouraged at any stage of airflow limitation. ${ }^{15}$

\section{Therapy}

The treatment of COPD patients cannot be "one size fits all". The overall assessment of the disease must include measurements of lung function and symptoms, as well as estimation of exacerbations and comorbidities. ${ }^{1}$ It has been suggested that it might be possible to link the therapy to the patient's phenotype, ${ }^{120-122}$ and this concept deserves further investigation. ${ }^{18,52,100,123,124}$ However, although it does not reflect either the severity of the overall disease $e^{57,125}$ or the total impairment in lung function, ${ }^{126}$ the measurement of the $\mathrm{FEV}_{1} \%$ predicted remains a milestone variable in all clinical trials in COPD.

Traditionally, clinical trials on COPD therapy have recruited patients with postbronchodilator $\mathrm{FEV}_{1}$ : $\mathrm{FVC}<0.7$ and $\mathrm{FEV}_{1}<80 \%$, thus excluding patients with mild airflow limitation. ${ }^{19,77,125,127}$ However, real-life studies have shown than not only patients with mild airflow limitation are treated ${ }^{20}$ and even over-treated ${ }^{19,21}$ but also that symptomatic subjects with normal spirometry receive prescriptions of bronchodilators and inhaled corticosteroids. ${ }^{14,31,32}$ The only study specifically addressing GOLD 1 patients was that done by O'Donnell et al, ${ }^{128}$ who performed a short-term, randomized, double-blind, placebo-controlled, crossover clinical trial in COPD patients with mild airflow limitation, measuring lung function and exercise tests after either placebo or the nebulizer ipratropium bromide $500 \mu \mathrm{g}$. Interestingly, the mean baseline modified Medical Research Council dyspneascale score was $>1$, suggesting the presence of symptoms even with postbronchodilator $\mathrm{FEV}_{1}$ averaging $90 \%$ predicted. Mean postbronchodilator $\mathrm{FEV}_{1}: \mathrm{FVC}$ was $<0.6$, and lung volumes showed a slight degree of lung hyperinflation, while $\mathrm{DL}_{\mathrm{CO}}$ and maximum pressures were well within the normal limits, while airway resistance increased. Symptom-limited $\dot{\mathrm{V}}_{\mathrm{O}_{2}}$ averaged $1.8 \mathrm{~L} / \mathrm{min}$, ie, $79 \%$ predicted. O'Donnell et al ${ }^{128}$ found that treatment with a short-acting bronchodilator, ie, ipratropium bromide, was associated with a significant improvement in $\mathrm{FEV}_{1}$, airway resistance, and RV. During exercise, there was a significant increase in dynamic inspiratory capacity, though there was no improvement in endurance time. The reduction in dynamic hyperinflation was linked to a reduction in ratings of exertional dyspnea intensity at higher levels of ventilation. The authors suggested that this study provided a physiologic rationale for considering a trial of bronchodilating therapy in COPD patients with mild airflow limitation who experience activity-related dyspnea. Casaburi et al ${ }^{129}$ investigated the effect of tiotropium on pulmonary hyperinflation and exercise tolerance in symptomatic patients with mild-moderate airflow limitation (GOLD 1 and 2). ${ }^{53}$ In that 22-week, randomized, crossover study, they found that tiotropium improved inspiratory capacity in both groups of GOLD 1 and 2 patients, whereas exercise duration was enhanced only in group 2 (moderate airflow limitation). 
The lack of effect of tiotropium on exercise tolerance, despite the significant reduction in dynamic lung hyperinflation in GOLD 1, was only partially explained by a limitation of the study protocol. Additional research on GOLD 1 patients was encouraged.

A few studies in the 90 s recruited COPD patients with mild-moderate airflow limitation in prospective trials. The longest period of observation, 11 years, was obtained in the Lung Health Study on smoking cessation, ${ }^{130}$ which showed that smoking cessation was effective to slow $\mathrm{FEV}_{1}$ decline significantly and quite substantially in sustained quitters compared to intermittent quitters and continuous smokers, particularly in COPD with mild airflow limitation. ${ }^{46}$ By contrast, three prospective clinical trials, lasting $4^{131}$ and $3^{132,133}$ years, failed to show any effect of inhaled corticosteroids in the rate of $\mathrm{FEV}_{1}$ decline in patients with mild-moderate COPD. In the Copenhagen study, ${ }^{132}$ mean $\mathrm{FEV}_{1}$ was $>80 \%$ predicted, suggesting a high proportion of patients with mild rather than moderate COPD. That study failed to find any effect of budesonide on symptoms and exacerbations. An interesting observation in EUROSCOPE ${ }^{133}$ was the $\mathrm{FEV}_{1}$ improvement in the budesonide group $(+17 \mathrm{~mL}$ on average) and not in the placebo group ( $-81 \mathrm{~mL}$ on average) in the first 6 months of the study. Afterward, the decline progressed at a similar rate from the 9th month to the end of treatment. A 5-year follow-up clinical trial compared the effect of inhaled ipratropium with placebo, and an aggressive smoking-intervention program, in COPD patients with mild-moderate airflow limitation: the use of the bronchodilator did not influence the long-term decline in $\mathrm{FEV}_{1} \cdot{ }^{134}$

On the basis of the available evidence, it may be concluded that in COPD patients with mild airflow limitation:

- smoking cessation is the most effective measure to decrease the rate of $\mathrm{FEV}_{1}$ decline;

- changes in lifestyle toward more active physical activity must be encouraged;

- a short-acting muscarinic antagonist can improve lung function, at least in the short run, but influences the rate of $\mathrm{FEV}_{1}$ decline;

- regular monotherapy with inhaled corticosteroids does not reduce either the rate of decline of $\mathrm{FEV}_{1}$ or the rate of exacerbations; however, a rich body of data in a recent publication suggests that a substantial proportion of patients with COPD may not have rapid $\mathrm{FEV}_{1}$ decline, which for decades has been regarded as the hallmark of COPD. ${ }^{135}$

The last point has important implications for future research on mild COPD. In fact, it suggests that different end points should be considered to assess the effect of treatments on the progression of the disease, eg, other tests of lung function, exacerbations, quality of life, and symptoms. ${ }^{31,47}$

\section{Pulmonary function tests}

In this document, we are not addressing the investigation of lung function in smokers, either with or without symptoms, with spirometry within normal limits and possibly smallairway disease. ${ }^{14,31}$ Furthermore, we are not addressing the longstanding question of whether a fixed $\mathrm{FEV}_{1}$ :FVC $<0.7$ or $<\mathrm{LLN}$ ratio should be preferred; ${ }^{1}$ nor are we debating whether FVC or VC should be the denominator. ${ }^{125}$ However, the GLI approach ${ }^{8,12}$ is discussed in this article because it may be a major topic of future research. For this article, we accept the operational definition adopted in most articles on patients with a diagnosis of COPD and mild airflow limitation. ${ }^{53,89}$ However, on the basis of the available evidence, we recommend some additional physiologic measurements, which may provide a better understanding of lung abnormalities, in particular in patients with such symptoms as dyspnea ${ }^{14,31}$ and/or chronic cough and sputum. ${ }^{136}$

\section{Lung volume}

TLC is needed to distinguish between a true obstructive pattern (TLC within normal limits or above LLN) or a mixed obstructive/restrictive pattern (TLC $<$ LLN). ${ }^{6}$ FRC may be increased above normal limits, due to static pulmonary hyperinflation. ${ }^{126} \mathrm{RV}$ is likely to be above normal limits, due to premature airway closure during forced expiration. ${ }^{58,137}$ TLC, FRC, and RV are expected to increase progressively with advancement of the disease. ${ }^{138}$

\section{Diffusing capacity $\left(\mathrm{DL}_{\mathrm{co}}\right.$ or $\left.\mathrm{TL}_{\mathrm{co}}\right)$}

The transfer factor of carbon monoxide $\left(\mathrm{TL}_{\mathrm{CO}}\right)$ or diffusing capacity $\left(\mathrm{DL}_{\mathrm{CO}}\right)^{139}$ can be abnormal in smokers with otherwise-preserved lung function; ${ }^{80}$ in particular the carbon monoxide transfer coefficient ${ }^{140}$ is significantly correlated with the amount of emphysema in smokers. A low baseline carbon monoxide transfer coefficient is independently associated with more rapid progression of emphysema and airflow limitation in heavy smokers. ${ }^{141} \mathrm{TL}_{\mathrm{CO}}$ measurement can provide additional prognostic information in COPD patients on follow-up. ${ }^{142}$ Low $\mathrm{DL}_{\mathrm{CO}}$ is a predictor of future airflow obstruction in smokers with normal spirometry. ${ }^{93}$

\section{Cardiopulmonary exercise test}

In an elegant series of studies, O'Donnell et al clearly showed that compared to a matched control group, COPD patients with mild airflow limitation ${ }^{13}$ during exercise:

- develop dynamic lung hyperinflation; ${ }^{89}$ 
- can exhibit a significant degree of electromechanical uncoupling; 92

- have high $\mathrm{V}_{\mathrm{D}}: \mathrm{V}_{\mathrm{T}}$, which is the most consistent gasexchange abnormality. ${ }^{91}$

\section{Respiratory impedance}

It has been shown that the impulse-oscillation system allows determination of respiratory impedance and frequency dependence of resistance and has the potential to detect lung pathology in patients with COPD earlier than spirometry. ${ }^{90}$ Therefore, smokers with a diagnosis of COPD and mild airflow obstruction should be carefully studied to explain symptoms, when present, and to establish a time 0 (baseline) for follow-up. ${ }^{140,141}$

\section{Follow-up}

After the seminal study by Fletcher and Peto, ${ }^{33}$ the rate of $\mathrm{FEV}_{1}$ decline over time has been suggested as the milestone variable to assess the progressive loss of lung function in COPD. However, the most recent GOLD document suggests that symptoms and exacerbations are the crucial variables for follow-up, whereas lung function may not be needed. ${ }^{1}$ This concept, which makes the life of the busy clinician easier, might be appropriate for patients with the overt disease, but should not be applied to patients with mild airflow limitation whose symptoms are highly dependent on an active lifestyle, where exacerbations may be interpreted as common viral infections, as in the general population.

The physiologic drop in lung function found in otherwisehealthy nonsmokers has been reported as up to $30 \mathrm{~mL} /$ year, and is accelerated in smokers up to a mean $80 \mathrm{~mL} /$ year. ${ }^{33}$ However, the trajectories leading to COPD include not only rapid $\mathrm{FEV}_{1}$ decline but also normal rate of decay with lower starting value, eg, due to childhood respiratory illness. ${ }^{38,143}$ A population-based study reported data over 11 years of observation in subjects with respiratory symptoms and normal lung function and GOLD 1 or more. ${ }^{45}$ Overall, $\mathrm{FEV}_{1}$ decline was greater in GOLD 1 patients than in normal subjects, and within stage 1 it was greater in those with respiratory symptoms than without. ${ }^{45}$ This was associated with increased utilization of respiratory care resources and lower health-related quality of life; ${ }^{45}$ the asymptomatic GOLD 1 patients being similar to the reference group of normal subjects. This is consistent with the observation that symptoms of chronic bronchitis without airflow obstruction are a risk factor for the development of COPD. ${ }^{144}$

Thoracic CT has been used to investigate the small airways and the periphery of the lungs. Recent publications have shown that CT-assessed functional small-airway disease and emphysema are associated with $\mathrm{FEV}_{1}$ decline, but the association with functional airway disease has greatest importance in mild-moderate COPD, where the rate of $\mathrm{FEV}_{1}$ decline is greatest. ${ }^{43,99}$ The COPDGene study showed that the rate of $\mathrm{FEV}_{1}$ decline was higher in GOLD 1 than GOLD 2 and above, and that it was fostered by severe exacerbations. ${ }^{47}$

All these data support the idea that repeated measurements of $\mathrm{FEV}_{1}$ should be performed in the follow-up of patients with GOLD 1 COPD, particularly in subjects with respiratory symptoms and exacerbations. Clearly, CT is an excellent tool for research, but it cannot be proposed for clinical practice, at least at present. ${ }^{47,99,124}$

A few years ago, Macklem suggested a different perspective to look at the natural history of COPD. ${ }^{138}$ Rather than focusing on $\mathrm{FEV}_{1}$ decline, he pointed attention to the progressive rise in static lung volume, ie, lung hyperinflation. ${ }^{126}$ Due to the loss of lung elastic recoil and small-airway closure at higher volumes, RV, FRC, and TLC increase, while VC, FVC, and $\mathrm{FEV}_{1}$ decrease. The fall in VC (or FVC) brings to the drop in $\mathrm{FEV}_{1}$, according to the formula $\mathrm{FEV}_{1}=\left(\mathrm{FEV}_{1}: \mathrm{VC}\right) / \mathrm{VC}$. Although specific research on the natural history of COPD patients with mild airflow limitation is lacking, the analysis from Macklem suggests that the measurement of changes in lung volume might be convenient for assessing the evolution of COPD. In this respect, the Swedish study (SCAPIS), ${ }^{145}$ which showed that the $\mathrm{FEV}_{1}: \mathrm{VC}$ ratio is more sensitive than the $\mathrm{FEV}_{1}: \mathrm{FVC}$ ratio in detecting the spirometric abnormalities of COPD, has to be mentioned. That study concluded that the use of only FVC when assessing airflow limitation may result in a considerable underdiagnosis of patients with mild airflow limitation. ${ }^{145}$ Therefore, once a diagnosis of COPD with mild airflow limitation is obtained, periodic spirometry can provide a simple and reliable parameter for follow-up of patients. In this connection, there are two factors to be considered. First, the history of either childhood or maternal asthma ${ }^{17,146,147}$ and early-life lower respiratory illness ${ }^{147}$ should be investigated carefully, particularly in never- or former-smoking subjects with mild but irreversible airflow limitation, as a risk factor for faster $\mathrm{FEV}_{1}$ decline in adulthood. Second, low $\mathrm{FEV}_{1}$ in early adulthood may lead to COPD without an accelerated decline in $\mathrm{FEV}_{1}{ }^{143}$ This emphasizes the need for more extensive use of spirometry early in life to disclose susceptible smokers, rapid $\mathrm{FEV}_{1}$ decliners (about $50 \mathrm{~mL} /$ year), or normal $\mathrm{FEV}_{1}$ decliners $(<30 \mathrm{~mL} /$ year $)$ starting from low $\mathrm{FEV}_{1}$.

Therefore, we support the idea that lung function should be measured for the follow-up of patients with GOLD 1 COPD. 
At present, the decision on the timing of measurement remains completely discretionary. It may depend upon the intensity of symptoms and exacerbations, age, and history of smoking, for example. Spirometry might be scheduled from 6 months to 2 years, according to the individual evaluation.

\section{Future research}

Many patients who meet the spirometric criteria of GOLD 1 COPD are asymptomatic at rest and at moderate levels of exercise. The immediate consequence of this fact is that it is not known to a great extent what the natural history of this COPD subtype and its specific treatment are. In our opinion, there is a need for future research in the following areas in COPD patients with mild airflow limitation.

\section{Diagnosis}

Undiagnosed COPD is associated with increased health care costs and more cardiovascular risk factors. ${ }^{148,149}$ Although undiagnosed subjects appeared healthier than those with a diagnosis, their risk of death was increased compared with subjects without obstruction. ${ }^{150}$ At present, we do not know the prevalence or outcomes of COPD with mild airflow limitation based on the LLN. Neither do we know if a change in the diagnosis of mild airflow limitation based on such criteria as the LLN and/or GLI Z-scores could be associated with a different clinical presentation. We propose the following initiatives:

- studies to compare prevalence, clinical presentation, and outcomes among individuals diagnosed with mild airflow limitation on the basis of $\mathrm{FEV}_{1}$ :FVC $<0.70$ with those among individuals diagnosed on the basis of $\mathrm{FEV}_{1}$ : FVC $<\mathrm{LLN}_{\text {or even }} \mathrm{FEV}_{1}: \mathrm{VC}<\mathrm{LLN}$;

- longitudinal studies addressing the GLI approach, using GLI prediction equations and $\mathrm{FEV}_{1} Z$-scores to delineate severity grades;

- studies to investigate whether measurements of lung volume add valuable information for the diagnosis of COPD when airflow limitation is classified as mild;

- studies to evaluate the impact of the diagnosis of COPD with mild airflow limitation among younger versus older individuals (ie, is it more important to general health to diagnose asymptomatic or paucisymptomatic GOLD 1 COPD in a 50-year-old than an 80-year-old?).

\section{Clinical assessment}

Most but not all COPD patients with mild airflow limitation are either current or ex-smokers with at least 10 pack-years of smoking history. At a primary care office, over a third of ex- and current smokers who were diagnosed with GOLD stage 1 COPD based on screening spirometry were asymptomatic at the time of testing. ${ }^{151}$ As such, any current or ex-smokers should be tested with spirometry, regardless of the presence of respiratory symptoms. ${ }^{152}$ The question remains as to what else to perform after COPD with mild airflow limitation has been diagnosed. Of course, a minimum of anthropometric measurements and chest X-ray must be obtained. However, further research is needed to determine:

- the role of $\mathrm{DL}_{\mathrm{CO}}$ and/or oscillatory resistance, and CT to identify subgroups of patients (phenotypes) with different clinical presentation and differential responses to treatment;

- whether different available indices of symptoms (eg, CAT), disease severity (ie, BODE index), coexistence comorbidities (ie, asthma, COTE index) or other measures (eg, lung function, CT findings, biomarkers) are useful surrogate markers of short-, medium-, or long-term patient-centered outcomes.

\section{Treatment}

It is believed that hospitalizations and deaths are relatively infrequent in COPD patients with mild airflow limitation. However, the information available is old and scarce. ${ }^{134}$ As in the rest of COPD patients, treatment goals should be focused on: 1) relieving patient symptoms, 2) slowing the progression of disease, and 3) mitigating the risk of the leading causes of hospitalization and mortality (cardiovascular disease and lung cancer). There is a need for:

- studies to clarify the appropriate approach and strategy to achieve abstinence from smoking (value to spirometry results, ie, effectiveness of pharmacological agents);

- pharmacological trials to analyze outcomes among GOLD stage 1 COPD subtypes (ie, current vs ex-smokers with or without coexistent asthma); it might be of interest to investigate whether long-acting bronchodilators, in particular antimuscarinic agents, anti-inflammatory drugs, or the combination of inhaled corticosteroids/long-acting $\beta_{2}$-agonists can provide more benefits in the early stage of the disease, rather than in the most advanced ones;

- different end points might be considered to assess the effectiveness of pharmacologic treatment, such as lung-function tests more closely related to the periphery of the lungs ( RV, diffusion capacity, exercise tolerance) than $\mathrm{FEV}_{1}$ decline, and relevant clinical outcomes, such as exacerbations;

- nonpharmacological trials (ie, rehabilitation and encouragement of active lifestyle plus smoking-cessation intervention); 
- real-life observational studies to assess advantages/ disadvantages of being treated with different therapeutic approaches (eg, risk of pneumonia [Does early intervention reduce disease progression?]).

\section{Conclusion}

It has been known for many years that significant pathophysiologic abnormalities can be detected in smokers with normal spirometry. Furthermore, recent data show that smokers can report respiratory symptoms and seek medication with spirometric values still within normal limits. These two pieces of information suggest that "mild" airflow limitation, in smokers at least, can reflect well-established disease and not just a negligible insult of an otherwise-sufficient health status. These patients should be encouraged to pursue an active life style, which is not only healthy but also unravels the reduced exercise tolerance and may support any smokingcessation program.

A diagnosis of COPD with mild airflow limitation helps in recognizing and adequately treating exacerbations that might otherwise be interpreted differently and underestimated. Finally, a follow-up program should be planned, both to understand whether "mild" is really "early" and to take any measurement (nonpharmacologic and pharmacologic) to prevent the progressive deterioration of health status. On one hand, any smoker or ex-smoker should undergo spirometry early in her/his health file; on the other hand, acute episodes should be regarded as possible exacerbations of undiagnosed COPD.

\section{Acknowledgments}

The authors acknowledge the scientific contribution of the following European Pulmonology Societies: AIPO Italian Association of Hospital Pulmonologists, Croatian Pulmonology Society, Croatian Thoracic Society, HTS Hellenic Thoracic Society, SEPAR - Spanish Society of Pneumology and Thoracic Surgery, Slovenian Respiratory Society. The authors would like to thank the staff of AIPO Ricerche (Milan, Italy) for editing assistance. This consensus document has been funded through an unrestricted educational grant from Teva.

\section{Disclosure}

The authors report no conflicts of interest in this work.

\section{References}

1. Vogelmeier CF, Criner GJ, Martínez FJ, et al. Global strategy for the diagnosis, management, and prevention of chronic obstructive lung disease 2017 report: GOLD executive summary. Eur Respir J. 2017;49: 1700214.
2. Murray CJ, Lopez AD. Measuring the global burden of disease. NEngl J Med. 2013;369:448-457.

3. Adeloye D, Chua S, Lee C, et al. Global and regional estimates of COPD prevalence: systematic review and meta-analysis. J Glob Health. 2015;5:020415.

4. Rycroft CE, Heyes A, Lanza L, Becker K. Epidemiology of chronic obstructive pulmonary disease: a literature review. Int JChron Obstruct Pulmon Dis. 2012;7:457-494.

5. Soriano JB, Zielinski J, Price D. Screening for and early detection of chronic obstructive pulmonary disease. Lancet. 2009;374:721-732.

6. Pellegrino R, Viegi G, Brusasco V, et al. Interpretative strategies for lung function tests. Eur Respir J. 2005;26:948-968.

7. Güder G, Brenner S, Angermann CE, et al. GOLD or lower limit of normal definition? A comparison with expert-based diagnosis of chronic obstructive pulmonary disease in a prospective cohort-study. Respir Res. 2012;13:13.

8. Quanjer PH, Stanojevic S, Cole TJ, et al. Multi-ethnic reference values for spirometry for the 3-95-yr age range: the global lung function 2012 equations. Eur Respir J. 2012;40:1324-1343.

9. Vaz Fragoso CA, McAvay G, Van Ness PH, et al. Phenotype of normal spirometry in an aging population. Am J Respir Crit Care Med. 2015;192:817-825.

10. Vaz Fragoso CA, McAvay G, Van Ness PH, et al. Phenotype of spirometric impairment in an aging population. Am J Respir Crit Care Med. 2016;193:727-735.

11. Miller MR, Hankinson J, Brusasco V, et al. Standardisation of spirometry. Eur Respir J. 2005;26:319-338.

12. Quanjer PH, Pretto JJ, Brazzale DJ, Boros PW. Grading the severity of airways obstruction: new wine in new bottles. Eur Respir J. 2014; 43:505-512.

13. O'Donnell DE, Laveneziana P, Webb K, Neder JA. Chronic obstructive pulmonary disease: clinical integrative physiology. Clin Chest Med. 2014;35:51-69.

14. Elbehairy AF, Guenette JA, Faisal A. Mechanisms of exertional dyspnoea in symptomatic smokers without COPD. Eur Respir J. 2016;48: 694-705.

15. Watz H, Pitta F, Rochester CL, et al. An official European Respiratory Society statement on physical activity in COPD. Eur Respir J. 2014; 44:1521-1537.

16. Rennard S, Drummond MB. Early chronic obstructive pulmonary disease: definition, assessment, and prevention. Lancet. 2015;385: 1778-1788.

17. Martinez FD. Early-life origins of chronic obstructive pulmonary disease. $N$ Engl J Med. 2016;375:871-878.

18. Hurst JR, Vestbo J, Anzueto A, et al. Susceptibility to exacerbation in chronic obstructive pulmonary disease. $N$ Engl J Med. 2010;363: $1128-1138$.

19. Corrado A, Rossi A. How far is real life from COPD therapy guidelines? An Italian observational study. Respir Med. 2012;106:989-997.

20. Kardos P, Vogelmeier C, Worth H, et al. A two-year evaluation of the 'real life' impact of COPD on patients in Germany: the DACCORD observational study. Respir Med. 2017;124:57-64.

21. Price D, West D, Brusselle G. Management of COPD in the UK primarycare setting: an analysis of real-life prescribing patterns. Int J Chron Obstruct Pulmon Dis. 2014;9:889-904.

22. Rodriguez-Roisin R, Drakulovic M, Rodriguez DA, Roca J, Barberà JA, Wagner PD. Ventilation-perfusion imbalance and chronic obstructive pulmonary disease staging severity. J Appl Physiol (1985). 2009;106: 1902-1908.

23. Calverley P. Mild chronic obstructive pulmonary disease does exist and affects gas exchange during exercise. Am J Respir Crit Care Med. 2015;191:1346-1347.

24. Hogg JC, Macklem PT, Thurlbeck WM. Site and nature of airway obstruction in chronic obstructive lung disease. NEngl J Med. 1968;278: $1355-1360$

25. Hogg JC, Chu F, Utokaparch S, et al. The nature of small-airway obstruction in chronic obstructive pulmonary disease. $N$ Engl J Med. 2004; 350:2645-2653 
26. Cosio M, Ghezzo H, Hogg JC, et al. The relations between structural changes in small airways and pulmonary-function tests. $N$ Engl J Med. 1978;298:1277-1281.

27. Buist AS, Ross BB. Quantitative analysis of the alveolar plateau in the diagnosis of early airway obstruction. Am Rev Respir Dis. 1973;108: 1078-1087.

28. Verbanck S, Schuermans D, Paiva M, Meysman M, Vincken W. Small airway function improvement after smoking cessation in smokers withou airway obstruction. Am J Respir Crit Care Med. 2006;174:853-857.

29. Stănescu D, Sanna A, Veriter C, Robert A. Identification of smokers susceptible to development of chronic airflow limitation: a 13-year follow-up. Chest. 1998;114(2):416-425.

30. Hogg JC, Paré PD, Hackett TL. The contribution of small airway obstruction to the pathogenesis of chronic obstructive pulmonary disease. Physiol Rev. 2017;97:529-552.

31. Woodruff PG, Barr RG, Bleecker E, et al. Clinical significance of symptoms in smokers with preserved lung function. N Eng J Med.2016; 374:1811-1821.

32. Regan EA, Lynch DA, Curran-Everett D, et al. Clinical and radiologic disease in smokers with normal spirometry. JAMA. 2015;175:1539-1549.

33. Fletcher $\mathrm{C}$, Peto R. The natural history of chronic airflow obstruction. Br Med J. 1977; 1:1645-1648.

34. Soriano JB, Agusti A. Investigating the natural history of lung function: facts, pitfalls, and opportunities. Chest. 2009;135:1330-1341.

35. Kohansal R, Martinez-Camblor P, Agusti A, Buist AS, Mannino DM, Soriano JB. The natural history of chronic airflow obstruction revisited: an analysis of the Framingham Offspring cohort. Am J Respir Crit Care Med. 2009;180:3-10.

36. Vestbo J, Edwards LD, Scanlon PD, et al. Changes in forced expiratory volume in 1 second over time in COPD. $N$ Engl J Med. 2011;365 1184-1192.

37. McGeachie MJ, Yates KP, Zhou X, et al. Patterns of growth and decline in lung function in persistent childhood asthma. N Engl J Med. 2016;374:1842-1852.

38. Burrows B, Knudson RJ, Lebowitz MD. The relationship of childhood respiratory illness to adult obstructive airway disease. Am Rev Respir Dis. 1977;115:751-760.

39. Kerstjens HA, Rijcken B, Schouten JP, Postma DS. Decline of FEV by age and smoking status: facts, figures, and fallacies. Thorax. 1997; 52:820-827.

40. de Marco R, Accordini S, Cerveri I, et al. An international survey of chronic obstructive pulmonary disease in young adults according to GOLD stages. Thorax. 2004;59:120-125.

41. Miravitlles M, Soriano JB, Garcia-Rio F, et al. Prevalence of COPD in Spain: impact of undiagnosed COPD on quality of life and daily life activities. Thorax. 2009;64:863-868.

42. Scanlon PD, Connett JE, Waller LA, Altose MD, Bailey WC, Buist AS. Smoking cessation and lung function in mild-to-moderate chronic obstructive pulmonary disease: the Lung Health Study. Am J Respir Crit Care Med. 2000;161:381-390.

43. Tantucci C, Modina D. Lung function decline in COPD. Int J COPD. 2012;7:95-99.

44. Jones R, Ostrem A. Optimising pharmacological maintenance treatment for COPD in primary care. Prim Care Respir J. 2011;20:33-45.

45. Bridevaux PO, Gerbase MW, Probst-Hensch NM, Schindler C, Gaspoz JM, Rochat T. Long-term decline in lung function, utilisation of care and quality of life in modified GOLD stage 1 COPD. Thorax. 2008;63:768-774.

46. Kanner RE, Anthonisen NR, Connett JE. Lower respiratory illnesses promote $\mathrm{FEV}_{1}$ decline in current smokers but not ex-smokers with mild chronic obstructive pulmonary disease: results from the Lung Health Study. Am J Respir Crit Care Med. 2001;164:358-364.

47. Dransfield MT, Kunisaki KM, Strand MJ, et al. Acute exacerbations and lung function loss in smokers with and without COPD. Am J Respir Crit Care Med. 2017;195:324-330.

48. Omachi TA, Katz PP, Yelin EH, et al. Depression and health-related quality of life in chronic obstructive pulmonary disease. Am J Med. 2009;122: 778.e9-e15.
49. de Torres JP, Marin JM, Casanova C, et al. Lung cancer in patients with chronic obstructive pulmonary disease: incidence and predicting factors. Am J Respir Crit Care Med. 2011;184:913-919.

50. Lomas DA, Silverman EK, Edwards LD, Miller BE, Coxson HO, Tal-Singer R. Evaluation of serum CC-16 as a biomarker for COPD in the ECLIPSE cohort. Thorax. 2008;63:1058-1063.

51. Lomas DA, Silverman EK, Edwards LD, et al. Serum surfactant protein D is steroid sensitive and associated with exacerbations of COPD. Eur Respir J. 2009;34:95-102.

52. Agustí A, Edwards LD, Rennard SI, et al. Persistent systemic inflammation is associated with poor clinical outcomes in COPD: a novel phenotype. PLoS One. 2012;7:e37483.

53. Rabe KF, Hurd S, Anzueto A, et al. Global strategy for the diagnosis, management, and prevention of chronic obstructive pulmonary disease: GOLD executive summary. Am J Respir Crit Care Med. 2007;176: 532-555.

54. Buist AS, McBurnie MA, Vollmer WM, et al. International variation in the prevalence of COPD (the BOLD study): a population-based prevalence study. Lancet. 2007;370:741-750.

55. Lamprecht B, McBurnie MA, Vollmer WM, et al. COPD in never smokers: results from the population-based burden of obstructive lung disease study. Chest. 2011;139:752-763.

56. Lange P, Marott JL, Vestbo J. Prediction of the clinical course of chronic obstructive pulmonary disease, using the new GOLD classification: a study of the general population. Am J Respir Crit Care Med. 2012;186:975-981.

57. Vestbo J, Hurd SS, Agustí AG, et al. Global strategy for the diagnosis, management, and prevention of chronic obstructive pulmonary disease: GOLD executive summary. Am J Respir Crit Care Med. 2013; 187:347-365.

58. Milic-Emili J. Does mechanical injury of the peripheral airways play a role in the genesis of COPD in smokers? COPD. 2004;1:85-92.

59. Cosio MG, Saetta M, Agusti A. Immunologic aspects of chronic obstructive pulmonary disease. N Engl J Med. 2009;360:2445-2454.

60. Hogg JC, McDonough JE, Suzuki M. Small airway obstruction in COPD: new insights based on micro-CT imaging and MRI imaging. Chest. 2013;143:1436-1443.

61. Chilosi M, Carloni A, Rossi A, Poletti V. Premature lung aging and cellular senescence in the pathogenesis of idiopathic pulmonary fibrosis and COPD/emphysema. Transl Res. 2013;162:156-173.

62. Faner R, Rojas M, Macnee W, Agustí A. Abnormal lung aging in chronic obstructive pulmonary disease and idiopathic pulmonary fibrosis. $\mathrm{AmJ}$ Respir Crit Care Med. 2012;186:306-313.

63. MacNee W. Accelerated lung aging: a novel pathogenic mechanism of chronic obstructive pulmonary disease (COPD). Biochem Soc Trans. 2009;37:819-823.

64. Svanes C, Sunyer J, Plana E, et al. Early life origins of chronic obstructive pulmonary disease. Thorax. 2010;65:14-20.

65. Molfino NA. Genetic predisposition to accelerated decline of lung function in COPD. Int J Chron Obstruct Pulmon Dis. 2007;2: 117-119.

66. Savale L, Chaouat A, Bastuji-Garin S, et al. Shortened telomeres in circulating leukocytes of patients with chronic obstructive pulmonary disease. Am J Respir Crit Care Med. 2009;179:566-571.

67. Vanfleteren LE, Spruit MA, Groenen M, et al. Clusters of comorbidities based on validated objective measurements and systemic inflammation in patients with chronic obstructive pulmonary disease. Am J Respir Crit Care Med. 2013;187:728-735.

68. Alder JK, Guo N, Kembou F, et al. Telomere length is a determinant of emphysema susceptibility. Am J Respir Crit Care Med. 2011;184: 904-912.

69. Togo S, Holz O, Liu X, et al. Lung fibroblast repair functions in patients with chronic obstructive pulmonary disease are altered by multiple mechanisms. Am J Respir Crit Care Med. 2008;178:248-260.

70. Kasahara Y, Tuder RM, Cool CD, Lynch DA, Flores SC, Voelkel NF. Endothelial cell death and decreased expression of vascular endothelial growth factor and vascular endothelial growth factor receptor 2 in emphysema. Am J Respir Crit Care Med. 2001;163:737-744. 
71. Horowitz JC, Martinez FJ, Thannickal VJ. Mesenchymal cell fate and phenotypes in the pathogenesis of emphysema. COPD. 2009;6: 201-210.

72. Paschalaki K, Starke RD, Mercado N, Haskard DO, Barnes PJ, Randi AM. Endothelial colony forming cells (ECFC) are senescent and dysfunctional in COPD due to reduced sirtuin-1 levels. Heart. 2011;97:e7.

73. Giordano RJ, Lahdenranta J, Zhen L, et al. Targeted induction of lung endothelial cell apoptosis causes emphysema-like changes in the mouse. J Biol Chem. 2008;283:29447-29460.

74. Liu H, Fergusson MM, Castilho RM, et al. Augmented Wnt signaling in a mammalian model of accelerated aging. Science. 2007;317:803-806.

75. Meshorer E, Gruenbaum Y. Gone with the Wnt/Notch: stem cells in laminopathies, progeria, and aging. J Cell Biol. 2008;181:9-13.

76. Wang R, Ahmed J, Wang G, et al. Down-regulation of the canonical Wnt $\beta$-catenin pathway in the airway epithelium of healthy smokers and smokers with COPD. PLoS One. 2011;6:e14793.

77. Kneidinger N, Yildirim AO, Callegari J, et al. Activation of the WNT/ $\beta$-catenin pathway attenuates experimental emphysema. Am J Respir Crit Care Med. 2011;183:723-733.

78. Amsellem V, Gary-Bobo G, Marcos E, et al. Telomere dysfunction causes sustained inflammation in chronic obstructive pulmonary disease. Am J Respir Crit Care Med. 2011;184:1358-1366.

79. National Institute for Health and Care Excellence. Chronic Obstructive Pulmonary Disease in Over 16s: Diagnosis and Management of Chronic Obstructive Pulmonary Disease in Adults in Primary and Secondary Care. London: NICE; 2010.

80. Berend N, Woolcock AJ, Marlin GE. Correlation between the function and structure of the lung in smokers. Am Rev Respir Dis. 1979; 119:695-705.

81. Hogg JC. Identifying smokers at risk for developing airway obstruction. Chest. 1998;114:355.

82. Gennimata SA, Palamidas A, Karakontaki F, et al. Pathophysiology of evolution of small airways disease to overt COPD. COPD. 2010; 7:269-275.

83. Oxhoj H, Bake B, Wilhelmsen L. Ability of spirometry, flow-volume curves and the nitrogen closing volume test to detect smokers: a population study. Scand J Respir Dis. 1977;58:80-96.

84. Buist AS, Vollmer WM, Johnson LR, McCamant LE. Does the singlebreath $\mathrm{N}_{2}$ test identify the smoker who will develop chronic airflow limitation? Am Rev Respir Dis. 1988;137:293-301.

85. Verbanck S, Schuermans D, Meysman M, Paiva M, Vincken W. Noninvasive assessment of airway alterations in smokers: the small airways revisited. Am J Respir Crit Care Med. 2004;170:414-419.

86. Hutcheon M, Griffin P, Levison H, Zamel N. Volume of isoflow: a new test in detection of mild abnormalities of lung mechanics. Am Rev Respir Dis. 1974;110:458-465.

87. Nemery B, Moavero NE, Brasseur L, Stanescu DC. Significance of small airway tests in middle-aged smokers. Am Rev Respir Dis. 1981; 124:232-238.

88. Deesomchok A, Webb KA, Forkert L, et al. Lung hyperinflation and its reversibility in patients with airway obstruction of varying severity. COPD. 2010;7:428-437.

89. Ofir D, Laveneziana P, Webb KA, Lam YM, O'Donnell DE. Mechanisms of dyspnea during cycle exercise in symptomatic patients with GOLD stage I chronic obstructive pulmonary disease. Am J Respir Crit Care Med. 2008; 177:622-629.

90. Frantz S, Nihlén U, Dencker M, Engström G, Löfdahl CG, Wollmer P. Impulse oscillometry may be of value in detecting early manifestations of COPD. Respir Med. 2012;106:1116-1123.

91. Elbehairy AF, Ciavaglia CE, Webb KA, et al. Pulmonary gas exchange abnormalities in mild chronic obstructive pulmonary disease: implications for dyspnea and exercise intolerance. Am J Respir Crit Care Med. 2015;191:1384-1394.

92. Guenette JA, Chin RC, Cheng S, et al. Mechanisms of exercise intolerance in global initiative for chronic obstructive lung disease grade 1 COPD. Eur Respir J. 2014;44:1177-1187.
93. Harvey BG, Strulovici-Barel Y, Kaner RJ, et al. Risk of COPD with obstruction in active smokers with normal spirometry and reduced diffusion capacity. Eur Respir J. 2015;46:1589-1597.

94. Harvey BG, Strulovici-Barel Y, Kaner RJ, et al. Progression to COPD in smokers with normal spirometry/low DLCO using different methods to determine normal levels. Eur Respir J. 2016;47:1888-1889.

95. Barbera JA, Roca J, Ramirez J, Wagner PD, Ussetti P, RodriguezRoisin R. Gas exchange during exercise in mild chronic obstructive pulmonary disease: correlation with lung structure. Am Rev Respir Dis. 1991;144:520-525.

96. Levine G, Housley E, MacLeod P, Macklem PT. Gas exchange abnormalities in mild bronchitis and asymptomatic asthma. $N$ Eng $J$ Med. 1970;282:1277-1282.

97. Hueper K, Vogel-Claussen J, Parikh MA, et al. Pulmonary microvascular blood flow in mild chronic obstructive pulmonary disease and emphysema: the MESA COPD study. Am J Respir Crit Care Med. 2015;192:570-580.

98. Barr RG, Bluemke DA, Ahmed FS, et al. Percent emphysema, airflow obstruction, and impaired left ventricular filling. $N$ Engl J Med. 2010;362:217-227.

99. Bhatt SP, Soler X, Wang X, et al. Association between functional small airway disease and $\mathrm{FEV}_{1}$ decline in chronic obstructive pulmonary disease. Am J Respir Crit Care Med. 2016;194:178-184.

100. Camiciottoli G, Bigazzi F, Paoletti M, Cestelli L, Lavorini F, Pistolesi M. Pulmonary function and sputum characteristics predict CT phenotype and severity of COPD. Eur Respir J. 2013;42:626-635.

101. Schroeder JD, McKenzie AS, Zach JA, et al. Relationships between airflow obstruction and quantitative CT measurements of emphysema, air trapping, and airways in subjects with and without chronic obstructive pulmonary disease. AJR Am J Roentgenol. 2013;201:W460-W470.

102. Yuan R, Hogg JC, Pare PD, et al. Prediction of the rate of decline in $\mathrm{FEV}_{1}$ in smokers using quantitative computed tomography. Thorax. 2009;64:944-949.

103. Vestbo J, Anderson W, Coxon HQ, et al. Evaluation of COPD longitudinally to identify predictive surrogate end-points (ECLIPSE). Eur Respir J. 2008;31:869-873.

104. Jones JH, Zelt JT, Hirai DM, et al. Emphysema on thoracic CT and exercise ventilatory inefficiency in mild-to-moderate COPD. COPD. 2017;14:210-218.

105. Lee JH, Cho MH, McDonald ML, et al. Phenotypic and genetic heterogeneity among subjects with mild airflow obstruction in COPDGene. Respir Med. 2014;108:1469-1480.

106. Dirksen A, Wille MM. Computed tomography-based subclassification of chronic obstructive pulmonary disease. Ann Am Thorac Soc. 2016;13 (Suppl 2):S114-S117.

107. Decramer M, Rennard S, Troosters T, et al. COPD as a lung disease with systemic consequences: clinical impact, mechanisms, and potential for early intervention. COPD. 2008;5:235-256.

108. Welte T, Vogelmeier C, Papi A. COPD: early diagnosis and treatment to slow disease progression. Int J Clin Pract. 2015;69:336-349.

109. Probst-Hensch NM, Curjuric I, Pierre-Olivier B, et al. Longitudinal change of prebronchodilator spirometric obstruction and health outcomes: results from the SAPALDIA cohort. Thorax. 2010;65: $150-156$.

110. Janson C, Marks G, Buist S, et al. The impact of COPD on health status: findings from the BOLD study. Eur Respir J. 2013;42:1472-1483.

111. O'Reilly JF, Williams AE, Holt K, Rice L. Defining COPD exacerbation in chronic obstructive pulmonary disease. $N$ Engl J Med. 2010; $363: 1128-1138$.

112. Greenberg SB, Allen M, Wilson J, Atmar RL. Respiratory viral infection in adults with and without chronic obstructive pulmonary disease. Am J Respir Crit Care Med. 2000;162:167-173.

113. Agusti A, Calverley PA, Celli B, et al. Characterisation of COPD heterogeneity in the ECLIPSE cohort. Respir Res. 2010;11:122.

114. Van Remoortel H, Hornikx M, Demeyer H, et al. Daily physical activity in subjects with newly diagnosed COPD. Thorax. 2013;68: 962-963. 
115. Garcia-Aymerich J, Lange P, Benet M, Schnohr P, Antò JM. Regular physical activity modifies smoking-related lung function decline and reduces risk of chronic obstructive pulmonary disease: a populationbased cohort study. Am J Respir Crit Care Med. 2007;175:458-463.

116. Decramer M, Janssens W, Miravitlles M. Chronic obstructive pulmonary disease. Lancet. 2012;379:1341-1351.

117. Garcia-Aymerich J, Lange P, Benet M, Schnohr P, Antò JM. Regular physical activity reduces hospital admission and mortality in chronic obstructive pulmonary disease: a population based cohort study. Thorax. 2006;61:772-778.

118. Waschki B, Kirsten A, Holz O, et al. Physical activity is the strongest predictor of all-cause mortality in patients with COPD: a prospective cohort study. Chest. 2011;140:331-342.

119. Ng LW, Mackney J, Jenkins S, Hill K. Does exercise training change physical activity in people with COPD? A systematic review and meta-analysis. Chron Respir Dis. 2012;9:17-26.

120. Manini TM, Everhart JE, Patel KV, et al. Daily activity energy expenditure and mortality among older adults. JAMA. 2006;296:171-179.

121. Miravitlles M, Soler-Cataluña JJ, Calle M, Soriano JB. Treatment of COPD by clinical phenotypes: putting old evidence into clinical practice. Eur Respir J. 2013;41:1252-1256.

122. Miravitlles M, Soler-Cataluña JJ, Calle M, et al. Spanish Guideline for COPD (GesEPOC): update 2014. Arch Bronconeumol. 2014;50 (Suppl 1):1-16.

123. Subramanian DR, Gupta S, Burggraf D, et al. Emphysema- and airwaydominant COPD phenotypes defined by standardized quantitative computed tomography. Eur Respir J. 2016;48:92-103.

124. Lynch DA, Austin JH, Hogg JC, et al. CT-definable subtypes of chronic obstructive pulmonary disease: a statement of the Fleischner Society. Radiology. 2015;277:192-205.

125. Bettoncelli G, Blasi F, Brusasco V, et al. The clinical and integrated management of COPD. Sarcoidosis Vasc Diffuse Lung Dis. 2014; 31 (Suppl 1):3-21.

126. Rossi A, Aisanov Z, Avdeev S, et al. Mechanisms, assessment and therapeutic implications of lung hyperinflation in COPD. Respir Med. 2015;109:785-802.

127. Celli B, MacNee W. Standards for the diagnosis and treatment of patients with COPD: a summary of the ATS/ERS position paper. Eur Respir J. 2004;23:932-946.

128. O'Donnell DE, Laveneziana P, Ora J, Webb KA, Lam YM, Ofir D. Evaluation of acute bronchodilator reversibility in patients with symptoms of GOLD stage I COPD. Thorax. 2009;64:216-223.

129. Casaburi R, Maltais F, Porszasz J, et al. Effects of tiotropium on hyperinflation and treadmill exercise tolerance in mild to moderate chronic obstructive pulmonary disease. Ann Am Thorac Soc. 2014;11: 1351-1361.

130. Anthonisen NR, Connett JE, Murray RP. Smoking and lung function of Lung Health Study participants after 11 years. Am J Respir Crit Care Med. 2002;166:675-679.

131. Wise R, Connett J, Weinmann G, Scanlon P, Skeans M. Effect of inhaled triamcinolone on the decline in pulmonary function in chronic obstructive pulmonary disease. $N$ Engl J Med. 2000;343:1902-1909.

132. Vestbo J, Sørensen T, Lange P, Brix A, Torre P, Viskum K. Long term effect of inhaled budesonide in mild and moderate chronic obstructive pulmonary disease: a randomized controlled trial. Lancet. 1999; 353:1819-1823.

133. Pauwels RA, Lofdahl CG, Latijnen LA, et al. Long-term treatment with inhaled budesonide in persons with mild chronic obstructive pulmonary disease who continue smoking. $N$ Engl J Med. 1999;340: 1948-1953.
134. Anthonisen NR, Connett JE, Kiley JP, et al. Effects of smoking intervention and the use of an inhaled anticholinergic bronchodilator on the rate of decline of FEV : the Lung Health Study. JAMA. 1994; 272:1497-1505.

135. Tashkin DP, Celli B, Senn S, et al. A 4-year trial of tiotropium in chronic obstructive pulmonary disease. $N$ Engl J Med. 2008;359: $1543-1554$

136. Allison JP, Hardy R, Donaldson GC, et al. The presence of chronic mucus hyper secretion across adult life in relation to chronic obstructive pulmonary disease development. Am J Respir Crit Care Med. 2016;193: 662-672.

137. Milic-Emili J, Torchio R, D'Angelo E. Closing volume: a reappraisal (1967-2007). Eur J Appl Physiol. 2007;99:567-583.

138. Macklem PT. The therapeutic implications of the pathophysiology of COPD. Eur Respir J. 2010:35:676-680.

139. Hughes JM, Pride NB. In defence of the carbon monoxide transfer coefficient KCO (TL/V'A). Eur Respir J. 2001;17:168-174.

140. Hughes JM, Pride NB. Examination of the carbon monoxide diffusing capacity (DLCO) in relation to its KCO and V'A components. Am J Respir Crit Care Med. 2012;186:132-139.

141. Hoesein FA, Zanen P, van Ginneken, et al. Association of the transfer coefficient of the lung carbon monoxide with emphysema progression in male smokers. Eur Respir J. 2011;38:1012-1018.

142. Boutou AK, Shrilkrishna D, Tanner RJ, et al. Lung function indices for predicting mortality in COPD. Eur Respir J. 2013;42:616-625.

143. Lange P, Celli B, August A, et al. Lung-function trajectories leading to chronic obstructive pulmonary disease. $N$ Engl J Med. 2015;373: $111-122$.

144. de Marco R, Accordino S, Cerveri I, et al. Incidence of chronic obstructive pulmonary disease in a cohort of young adults according to the presence of chronic cough and phlegm. Am J Respir Crit Care Med. 2007; 175:32-39

145. Torén K, Olin AK, Lindberg A, et al. Vital capacity and COPD: the Swedish Cardiopulmonary Bioimage Study (SCAPIS). Int J Chron Obstruct Pulm Dis. 2016;11(1):927-933.

146. Grol MH, Gerritsen J, Vonk JM, et al. Risk factors for growth and decline of lung function in asthmatic individuals up to age 42 years: a 30-year follow-up study. Am J Respir Crit Care Med. 1999;160: 1830-1837.

147. Berry CE, Billheimer D, Jenkins IC, et al. A distinct low lung function trajectory from childhood to the fourth decade of life. Am J Respir Crit Care Med. 2016;194:607-612.

148. Akazawa M, Halpern R, Riedel AA, Stanford RH, Dalal A, Blanchette CM. Economic burden prior to COPD diagnosis: a matched case-control study in the United States. Respir Med. 2008;102: 1744-1752.

149. Mapel DW, Robinson SB, Dastani HB, Shah H, Phillips AL, Lydick E. The direct medical costs of undiagnosed chronic obstructive pulmonary disease. Value Health. 2008;11:628-636.

150. Martinez CH, Mannino DM, Jaimes FA, et al. Undiagnosed obstructive lung disease in the U.S: associated factors and long-term mortality. Ann Am Thorac Soc. 2015;12:1788-1795.

151. Bednarek M, Maciejewski J, Wozniak M, et al. Prevalence, severity and underdiagnosis of COPD in the primary care setting. Thorax. 2008;63:402-407.

152. Labaki WW, Martinez CH, Han MK. COPD in 2016: some answers, more questions. Lancet. 2016;4:941-943. 


\section{Supplementary materials}

In Slovenia, the National Institute of Public Health (NIJZ) is a state institution that reports on the prevalence of diseases at a national level. In Tables S1-S3, the data from year 2008 are presented in a small region of northern Slovenia (with prevalence of smoking, above average Slovenian level). The striking finding is the high prevalence of smoking in younger adults, which is increasing mostly in young women. The overall prevalence of COPD in that region is $5.7 \%$ and in smokers $16.6 \%$.

Table SI Smoking exposure and COPD prevalence from the year 2008

\begin{tabular}{|c|c|c|c|c|c|c|c|}
\hline \multicolumn{8}{|c|}{ Smoking exposure in the general population } \\
\hline \multicolumn{4}{|c|}{$\begin{array}{l}\text { Current smokers by age groups and gender, year } 2008 \\
\text { (estimation on sample size 7,706) }\end{array}$} & \multicolumn{4}{|c|}{$\begin{array}{l}\text { Past smokers by age groups and gender, year } 2008 \\
\text { (estimation on sample size 7,706) }\end{array}$} \\
\hline Age group & Men (\%) & Women (\%) & Total (\%) & Age group & Men (\%) & Women (\%) & Total (\%) \\
\hline $25-29$ & 26.3 & 19.4 & 22.3 & $25-29$ & 14.2 & 21.4 & 18.6 \\
\hline $30-34$ & 27.5 & 15.6 & 20.5 & $30-34$ & 23.1 & 19.3 & 20.8 \\
\hline $35-39$ & 25.0 & 17.8 & 20.5 & $35-39$ & 19.7 & 18.2 & 18.8 \\
\hline $40-44$ & 28.5 & 22.9 & 25.3 & $40-44$ & 27.5 & 26.9 & 27.1 \\
\hline $45-49$ & 22.9 & 20.8 & 21.7 & $45-49$ & 38.1 & 24.3 & 30.1 \\
\hline $50-54$ & 22.4 & 17.6 & 19.6 & $50-54$ & 40.4 & 24.9 & 31.3 \\
\hline $55-59$ & 17.8 & 14.3 & 15.8 & $55-59$ & 43.2 & 22.6 & 32.0 \\
\hline $60-64$ & 12.6 & 8.7 & 10.4 & $60-64$ & 44.7 & 17.9 & 30.0 \\
\hline $65-69$ & 7.7 & 4.8 & 6.2 & $65-69$ & 35.1 & 13.5 & 23.5 \\
\hline $70-74$ & 7.2 & 3.5 & 5.2 & $70-74$ & 40.2 & 12.3 & 25.3 \\
\hline Total & 19.33 & 14.73 & 16.65 & Total & 33.19 & 20.19 & 25.67 \\
\hline
\end{tabular}

Notes: Sourced from Cindi health monitor survey, 2008. University Clinic Respiratory and Allergic Diseases, Golnik, Slovenia. ${ }^{2}$

Table S2 Hospital admissions in the year 2007

\begin{tabular}{|c|c|c|c|}
\hline \multicolumn{4}{|c|}{ Prevalence of COPD in current smokers is $16.6 \%$} \\
\hline Age group & $5.7 \%$ prevalence & Number of & Proportion of individuals \\
\hline $40-75$ years & of COPD & hospitalizations & $\begin{array}{l}\text { having COPD and admitted } \\
\text { to hospital (\%) }\end{array}$ \\
\hline
\end{tabular}

\begin{tabular}{llll}
\hline 518,783 & 29,570 & 2,391 & 8.1
\end{tabular}

Note: Sourced from Institute for Public Health of Slovenia, Ljublijana, In-patient Statistics Database University Clinic of Respiratory and Allergic Diseases, Golnik, Slovenia, Estimation based on a survey focused on COPD Epidemiology within Pomurje Region, year 2006, sample size 2000, author Simona Slaček, General Hospital Murska Sobota. ${ }^{3}$ 
Table S3 Hospitalization costs in the year 2007

\begin{tabular}{|c|c|c|c|c|c|}
\hline $\begin{array}{l}\text { International } \\
\text { Classification of } \\
\text { Diseases (ICD) } \\
\end{array}$ & $\begin{array}{l}\text { Number } \\
\text { of cases }\end{array}$ & $\begin{array}{l}\text { DRG } \\
\text { Weight }\end{array}$ & $\begin{array}{l}\text { Average } \\
\text { length of stay } \\
\text { (days) }\end{array}$ & $\begin{array}{l}\text { Costs in } \\
\text { Euros per one } \\
\text { hospitalization }\end{array}$ & $\begin{array}{l}\text { Cost in Euros for } \\
\text { hospitalization of all patients } \\
\text { in certain ICD group }\end{array}$ \\
\hline $\mathrm{J} 40$ & 38 & 1.05 & 5.03 & I,322.475 & 50,254 \\
\hline $\mathrm{J} 410$ & 21 & 2.14 & 6.53 & $2,695.33$ & 56,602 \\
\hline J4II & 18 & 1.62 & 13.44 & $2,040.39$ & 36,727 \\
\hline $\mathrm{J} 42$ & 11 & 3.50 & 8.64 & $4,408.25$ & 48,491 \\
\hline J438 & 27 & 1.79 & 6.75 & $2,254.505$ & 60,872 \\
\hline J439 & 14 & 1.57 & 8.46 & I,977.4I5 & 27,684 \\
\hline J440 & 792 & 1.99 & 11.23 & $2,506.405$ & $\mathrm{I}, 985,073$ \\
\hline J44I & 769 & 1.78 & 10.33 & $2,241.91$ & I,724,029 \\
\hline J448 & 201 & 1.65 & 9.04 & $2,078.175$ & $4|7,7| 3$ \\
\hline J449 & 387 & 1.63 & 8.96 & $2,052.985$ & 794,505 \\
\hline J47 & 113 & 1.66 & 10.11 & $2,090.77$ & 236,257 \\
\hline Total & 2,391 & & 10.13 & & $5,438,206$ \\
\hline
\end{tabular}

Notes: Sourced from Institute for Public Health of Slovenia, Ljublijana, University Clinic of Respiratory and Allergic Diseases, Golnik, Slovenia. Cost estimation calculation factor based on ICD code.'

Abbreviation: DRG, diagnose related group.

Table S4 describes the trend of self-reported diagnosis of either asthma or chronic bronchitis (including COPD) in 2014 compared to 2007 in Slovenia. All answers of yes were supplemented by a doctor's confirmation of diagnosis.
Ten-year groups were created in the report of prevalence. The decrease in prevalence of both conditions is seen in the 7-year period.

Table S4 Prevalence of the disease

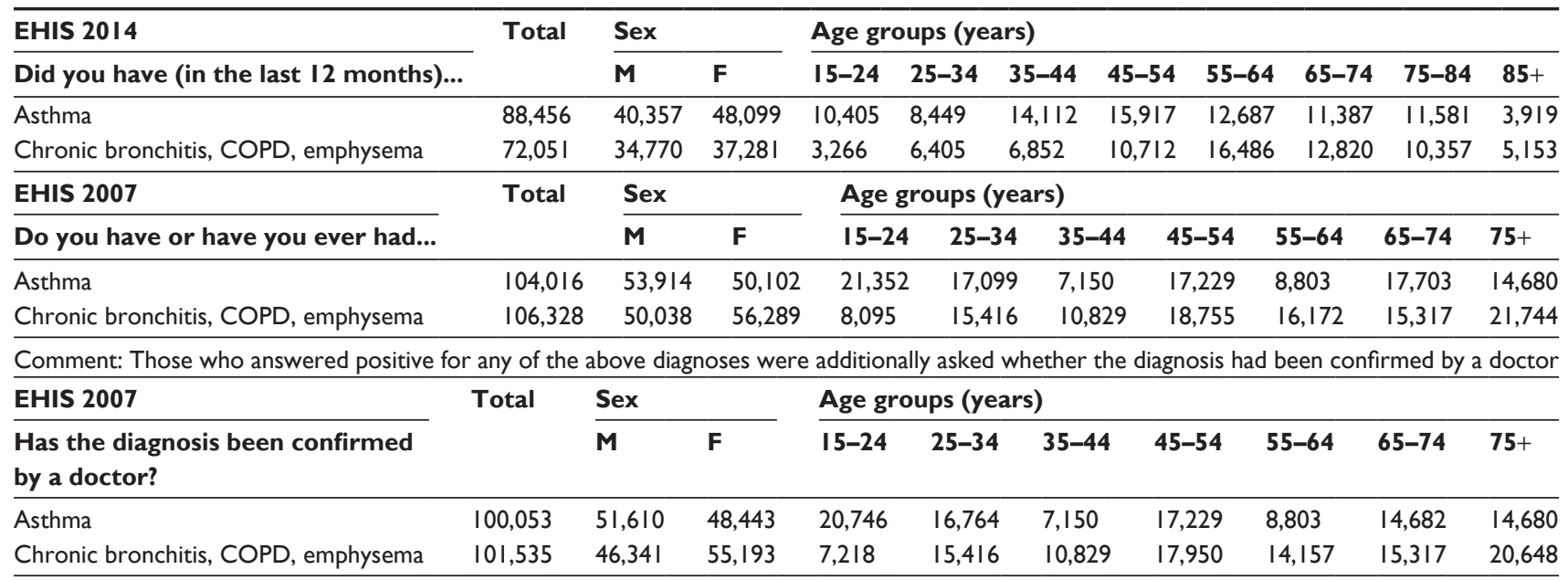

Comment: Those who answered positive for any of the above diagnoses, which were confirmed by a doctor, were additionally asked whether they had the disease in the last 12 months

\begin{tabular}{|c|c|c|c|c|c|c|c|c|c|c|}
\hline EHIS 2007 & Total & Sex & & Age gr & oups (ye & ars) & & & & \\
\hline Did you have the disease in the last 12 months? & & $\mathbf{M}$ & $\mathbf{F}$ & $15-24$ & $25-34$ & $35-44$ & $45-54$ & $55-64$ & $65-74$ & $75+$ \\
\hline Asthma & 60,091 & $3 I, 347$ & 28,743 & 7,835 & 6,947 & 4,271 & 12,256 & 8,032 & 11,957 & 8,793 \\
\hline Chronic bronchitis, COPD, emphysema & 54,039 & 19,768 & 34,271 & 393 & 4,271 & 3,946 & 11,853 & 8,750 & 9,742 & 15,085 \\
\hline
\end{tabular}

Notes: Residents of Slovenia (age > 15 years). From European Health Interview Surveys on health and health care, 2007 (EHIS 2007) and 2014 (EHIS 2014).'

Abbreviations: M, male; F, female; EHIS, European Health Interview Survey. 


\section{References}

1. Božič A, Zupanič T. Health and Health Care in Slovenia. Statistical Office of the Republic of Slovenia, 2009. Available from: http://www.nijz.si/sites/www.nijz.si/files/publikacije-datoteke/ health_and_healthcare_in_slovenia_0.pdf. Accessed June 7, 2017.

2. Ljubljana: Institute of Public Health of the Republic of Slovenia, 2010. Hlastan Ribic C, Djomba JK, Zaletel-Kragelj L (editors), et al. Tvegana vedenja, povezana z zdravjem in nekatera zdravstvena stanja pri odraslih prebivalcih Slovenije: Rezultati raziskave Dejavniki tveganja za nenalezljive bolezni pri odraslih prebivalcih Slovenije $2008-\mathrm{Z}$ zdravjem povezan vedenjski slog. Available from: https://www.dlib.si/details/ URN:NBN:SI:doc-9WUT23TJ. Accessed May 22, 2017.
3. Slaček S. Prevalenca obstruktivnega sindroma v Pomurju. In: Košnik M, editor. Obravnava bolnika na intenzivnem. Unit: 5. Golniški symposium Golnik, Brdo, 9th-14th October 2006. Golnik Hospital, Clinic of Respiratory and Allergic Diseases; 2006:127-128.

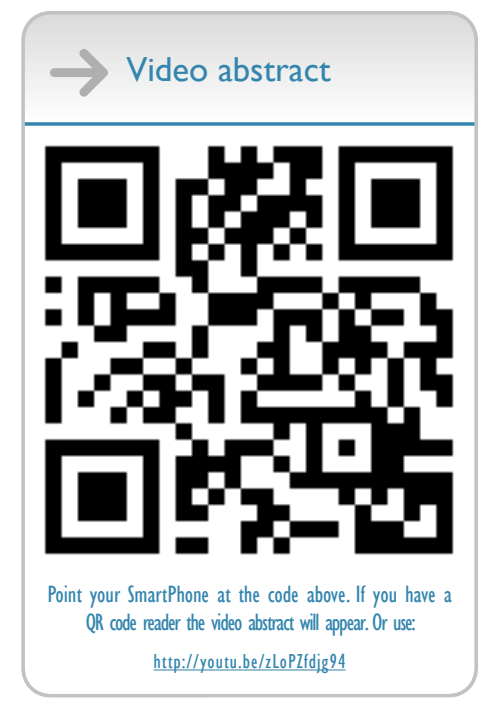

International Journal of COPD

\section{Publish your work in this journal}

The International Journal of COPD is an international, peer-reviewed journal of therapeutics and pharmacology focusing on concise rapid reporting of clinical studies and reviews in COPD. Special focus is given to the pathophysiological processes underlying the disease, intervention programs, patient focused education, and self management protocols.

This journal is indexed on PubMed Central, MedLine and CAS. The manuscript management system is completely online and includes a very quick and fair peer-review system, which is all easy to use. Visit $\mathrm{http} / / / \mathrm{www}$.dovepress.com/testimonials.php to read real quotes from published authors. 